\title{
Controls on the formation and size of potential landslide dams and dammed lakes in the Austrian Alps
}

\author{
Anne-Laure Argentin ${ }^{1}$, Jörg Robl ${ }^{1}$, Günther Prasicek ${ }^{1,2}$, Stefan Hergarten ${ }^{3}$, Daniel Hölbling ${ }^{4}$, Lorena Abad ${ }^{4}$, and \\ Zahra Dabiri ${ }^{4}$ \\ ${ }^{1}$ Department of Geography and Geology, University of Salzburg, 5020 Salzburg, Austria \\ ${ }^{2}$ Interdisciplinary Centre for Mountain Research, University of Lausanne, 1967 Bramois, Switzerland \\ ${ }^{3}$ Institute of Earth and Environmental Sciences, University of Freiburg, 79104 Freiburg, Germany \\ ${ }^{4}$ Department of Geoinformatics - Z_GIS, University of Salzburg, 5020 Salzburg, Austria
}

Correspondence: Anne-Laure Argentin (anne-laure.argentin@sbg.ac.at)

Received: 5 October 2020 - Discussion started: 3 November 2020

Revised: 17 April 2021 - Accepted: 23 April 2021 - Published: 27 May 2021

\begin{abstract}
Controls on landsliding have long been studied, but the potential for landslide-induced dam and lake formation has received less attention. Here, we model possible landslides and the formation of landslide dams and lakes in the Austrian Alps. We combine a slope criterion with a probabilistic approach to determine landslide release areas and volumes. We then simulate the progression and deposition of the landslides with a fluid dynamic model. We characterize the resulting landslide deposits with commonly used metrics, investigate their relation to glacial land-forming and tectonic units, and discuss the roles of the drainage system and valley shape. We discover that modeled landslide dams and lakes cover a wide volume range. In line with real-world inventories, we further found that lake volume increases linearly with landslide volume in the case of efficient damming - when an exceptionally large lake is dammed by a relatively small landslide deposit. The distribution and size of potential landslide dams and lakes depends strongly on local topographic relief. For a given landslide volume, lake size depends on drainage area and valley geometry. The largest lakes form in glacial troughs, while the most efficient damming occurs where landslides block a gorge downstream of a wide valley, a situation preferentially encountered at the transition between two different tectonic units. Our results also contain inefficient damming events, a damming type that exhibits different scaling of landslide and lake metrics than efficient damming and is hardly reported in inventories. We assume that such events also occur in the real world and em-
\end{abstract}

phasize that their documentation is needed to better understand the effects of landsliding on the drainage system.

\section{Introduction}

Landslides are a major threat to human lives and infrastructure in mountain ranges worldwide. Beyond the direct hazard due to the moving mass, landslides can initiate natural hazard cascades by damming rivers and initiating catastrophic flash floods and debris flows (e.g., Costa, 1985; Costa and Schuster, 1988; Cui et al., 2009). Through such long-range effects, even unwitnessed landslides occurring in remote areas matter. Many landslide dams tend to fail shortly after their formation (Tacconi Stefanelli et al., 2015), while resistant dams get filled by sediments, complicating their documentation and the assessment of their impoundment potential. Thus, most landslide dam and lake inventories only contain relatively large dams. Several geomorphometric indices have been developed to quantify the probability of landslides obstructing the valley and the stability of the resulting dams (Swanson et al., 1986; Canuti et al., 1998; Ermini and Casagli, 2002; Korup, 2004; Tacconi Stefanelli et al., 2016). However, studies on the formation of landslide dams and lakes, and on its dependence on factors that influence topography, such as contributing drainage area of rivers at their damming location, geologic preconditioning and long-term climatic forcing, are scarce. 
Contributing drainage area at the damming position has been considered an important variable in computing obstruction and stability indices (e.g., Ermini and Casagli, 2002; Korup, 2004; Tacconi Stefanelli et al., 2016; Swanson et al., 1986). This attention to drainage area is due to the long-term evolution of mountain landscapes: drainage area, as a proxy for discharge, is related to river flow length (Hack, 1957), channel slope (Flint, 1974) and river width (Finnegan et al., 2005; May et al., 2013). In particular, the latter two properties may exert a strong control on river damming by landslide deposits and on the volume of the thereby created lakes.

Mountain topography is conditioned by surface processes and the resistance of rocks against erosion. Both variables influence landslide occurrence (Hermanns and Strecker, 1999; Korup, 2008; Peruccacci et al., 2012) and likely exert control on dam and lake formation. Fluvial and glacial processes shape valleys and their flanks in typical ways. While fluvial valleys typically have a V-shaped cross section with a narrow floor and straight flanks, glaciers scour U-shaped valleys with wide and flat valley floors and flanks steepening uphill (e.g., Davis, 1906; Harbor and Wheeler, 1992; Prasicek et al., 2015). Sediment filling, however, may cause widening of both glacial and fluvial valley floors (Schrott et al., 2003), and hanging sections of glacial valleys may exhibit inner gorges - very narrow fluvially incised canyons (Montgomery and Korup, 2011).

Rock strength constrains the steepness of hillslopes (Selby, 1982; Montgomery, 2001). Thus, lithology has an impact on the valley's morphology, influencing both the valley floor and the valley flanks (Robl et al., 2015; Goudie, 2016; Baumann et al., 2018). Landslides can effectively dam rivers in narrow valleys, since landslide volumes required to impound the river flow are small. However, only small lakes can form in narrow and steep valleys. Further, the steepness and relief of the valley flanks control the spreading of the landslide mass as well as its runout. Thus, both surface processes and lithology may influence the formation of landslide dams and lakes.

From these considerations, the question arises of how potential landslide-dammed lakes are distributed across a mountain range and how dam and lake characteristics are related and vary regionally as a function of drainage area, topography and rock type. While landslides and their occurrence have been extensively studied, supported by monitoring techniques ranging from remote sensing to geophysics (e.g., Nichol and Wong, 2005; Hölbling et al., 2012; Stähli et al., 2015), modeling of landslide distribution (Hergarten, 2012) and susceptibility (Reichenbach et al., 2018), potential damming of rivers by landslides and resulting lakes has received less attention (Korup, 2005).

In this study, we combine numerical methods from the field of natural hazards with concepts of long-term landscape evolution. Therefore, we employ a modeling approach to investigate the influence of mountain topography, which differs in terms of predominant lithology and prevailing ero- sive surface processes (i.e., glacial versus fluvial conditions), on the potential occurrence of landslide dams and landslidedammed lakes, and on landslide and lake characteristics. We further calculate common landslide dam obstruction and stability indices, develop a simple approach to estimate the volume of potential landslide-dammed lakes, and compare our results to real-world inventories.

The Austrian Alps are a perfect natural laboratory to investigate the impact of differing landscape geometries on properties of potential landslide-dammed lakes. Beside the availability of a high-resolution DEM (Open Data Österreich, 2015), a detailed geological map (Bousquet et al., 2012; Schmid et al., 2004) and an extensive landslide inventory (Kuhn, visited 27 July 2020), the study area features various topographic patterns related to contrasting lithological units and different climatic forcing (e.g., Robl et al., 2015). The topographic evolution of the Eastern Alps, of which the Austrian Alps are an essential part, started with the Late Oligocene-Early Miocene indentation of the Adriatic microplate into Europe (e.g., Handy et al., 2015). While timing and rates of topography formation of various parts of the Eastern Alps are still debated (see Bartosch et al., 2017, and references therein), north-south shortening and crustal thickening in concert with fluvial dissection by major alpine drainage systems (e.g., Inn, Salzach, Enns, Mur, Drau drainage systems) caused the formation of mountainous topography, with deeply incised valleys separated by interfluves with mountain peaks rising above $3 \mathrm{~km}$. Located at mid-latitudes, the Austrian Alps were partly glaciated during the Pleistocene and still feature glaciers at the summit domains. While the topography in the western half of the study area was intensely reshaped by repeated glaciations, the eastern half shows a purely fluvial landscape (Fig. 3; Robl et al., 2008, 2015). Since major tectonic units with their characteristic lithological inventory strike west-east (Fig. 4; Bousquet et al., 2012; Schmid et al., 2004), we can directly compare the impact of glacially and fluvially dominated landscapes on occurrence and size of landslide-dammed lakes within individual tectonic units. This allows a distinction between lithological and climatic control.

\section{Materials and methods}

We use a novel combination of different numerical algorithms to model the formation of landslide dams and lakes. Our modeling workflow consists of three main steps: determination of landslide release areas and volumes, simulation of landslides, and computation of geomorphometric parameters of landslide dams. Finally, we use the retrieved information to characterize and discuss dam and lake formation (Fig. 1). 


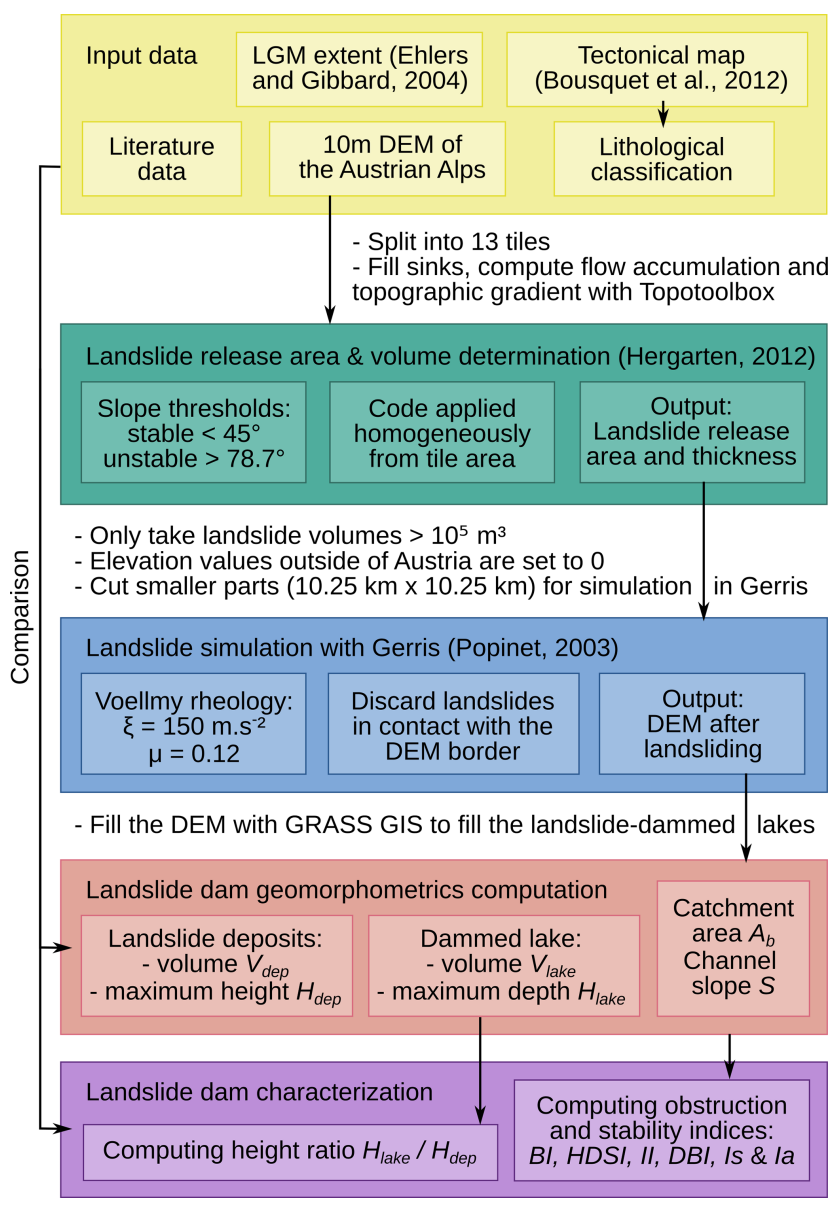

Figure 1. Workflow of modeled landslide dam creation across the Austrian Alps and their geomorphometric analysis.

\subsection{Topographical, glacial and geological datasets}

To model landslides we use a freely available lidar-based digital elevation model (DEM) of the Austrian Alps (Open Data Österreich, 2015) with a spatial resolution of $10 \mathrm{~m}$. The geophysical relief is based on the 1 arcsec ASTER GDEM V3 (NASA/METI/AIST/Japan Spacesystems and US/Japan ASTER Science Team, 2019). We use an Austrian landslide inventory containing the locations of 194 events (Kuhn, visited 27 July 2020). We consider the glacially overprinted terrains to be found within the mapped extent of the Last Glacial Maximum (LGM) originating from Ehlers and Gibbard (2004). We display the mapped tectonic units of the Alps (Fig. 4; Bousquet et al., 2012; Schmid et al., 2004) over the study area. However, the tectonic units are not homogeneous and comprise a high lithological and structural variability. Since lithology and discontinuities are a big control for erosion resistance, we do not venture to classify the tectonic units according to resistance to erosion.

\subsection{Geophysical relief}

We computed the geophysical relief of the study region with a circular moving window of $2.5 \mathrm{~km}$ radius. The topographic envelope is obtained by taking the maximum elevation within the moving window. A Gaussian filter is applied to smooth the resulting dataset. Geophysical relief is then computed by subtracting the actual topography from the topographic envelope.

\subsection{Determination of landslide release areas and volumes}

Determining locations prone to landsliding and the respective potential volumes is challenging, in particular for landslides in solid rock. The approach proposed by Hergarten (2012) still seems to be the only model which is able to predict the observed power-law distribution of rockfall and rockslide volumes in a simple and computationally efficient manner. The model is a combination of a geomorphometric analysis and a probabilistic approach. First, the algorithm stochastically chooses a seed pixel (i.e., a randomly picked pixel), then classifies the pixel slope to determine the stability of the local rock mass. Slope classification is based on lower and upper slope thresholds defining absolutely stable and absolutely unstable conditions, respectively. A linear increase in the probability of failure is assumed between these two limits. In case of failure, material is removed from the destabilized pixel until its slope reaches the minimum slope threshold. This local change of topography affects the slope of the adjacent pixels which are subsequently evaluated. In this way, the landslide area spreads until stable slope conditions at the seed pixel and its neighborhood are achieved. So the initiation of landslides depends on the local slope, while the final landslide size also depends on the size of sufficiently steep contiguous areas, which is related to the local relief.

For each seed pixel, the code finally outputs the area of the contiguous unstable pixels and the thickness of the substrate layer needed to be removed from each pixel to stabilize the area. In the next step, these data are used as release area and volume to model the landslides.

Hergarten (2012) found that the exponent of the landslide size distribution shows only a weak dependence on the threshold slopes $s_{\min }$ and $s_{\max }$, while the total number of events triggered and the maximum event size are strongly affected by these parameters. It can be expected that $s_{\min }$ and $s_{\max }$ depend on lithology. However, the dependency has not been investigated systematically so far. Hence, we use the same uniform slope threshold values, $s_{\min }=1\left(45^{\circ}\right)$ and $s_{\max }=5\left(79^{\circ}\right)$, applied by Hergarten (2012) to reproduce the distribution of landslide volumes in the Alps. Implications on landslide metrics and their spatial distribution are explained in detail in the "Discussion" section.

To avoid memory issues in the simulations, we split the DEM into 14 smaller tiles for computational reasons and in- 
troduce buffer frames to account for the runout of the landslides. We fill the sinks of the DEM and compute the flow accumulation and topographic gradient using TopoToolbox (Schwanghart and Kuhn, 2010; Schwanghart and Scherler, 2014).

\subsection{Landslide simulation}

Once the landslide release volumes have been determined, we simulate the runout of the landslides. As the model for the volume involves no timescale, it is assumed that the entire volume is released instantaneously.

We use a depth-averaged granular flow similar to shallowwater equations as introduced by Savage and Hutter (1989) in combination with the Voellmy rheology. In comparison with frictional and Bingham rheologies, the Voellmy rheology most accurately reproduces the debris deposition when simulating landslides with depth-averaged flow solvers (Hungr and Evans, 1996). This rheological model makes use of two parameters (Voellmy, 1955): a velocity squared drag coefficient $\xi$ (consisting of density and drag coefficient) and a dry friction coefficient $\mu$ (the ratio between the needed sliding force and the force perpendicular to the rupture surface). Drag increases with velocity. Hungr and Evans (1996) found values of $\xi$ ranging from 100 to $1000 \mathrm{~m} \mathrm{~s}^{-2}$, and values of $\mu$ from 0.03 to 0.24 by back-analyzing 23 rock avalanches. An analysis using Gerris with the Voellmy rheology on the 1987 Val Pola rock avalanche in Italy found that $\xi=150 \mathrm{~m} \mathrm{~s}^{-2}$ and $\mu=0.12$ are the most appropriate coefficients (Sanne, 2015).

Testing the influence of the two parameters, we found that they show no consistent influence on the modeled lake volume results (Fig. A1). While the velocity squared drag coefficient $\xi$ has only a slight negative impact on landslide deposit height, an increase in dry friction $\mu$ results - as expected - in notably higher values (Fig. A1b). However, neither $\xi$ nor $\mu$ does systematically change lake depths and volumes (Fig. A1a). This shows that, while maximum deposit heights increase, depths and volumes of dammed lakes and hence average geometries of landslides damming valleys are not consistently affected. Thus, we chose to keep the Voellmy coefficients determined by Sanne (2015). We do not take into account the entrainment of sediments and the loosening of bedrock, which could increase the volume of the detached mass.

Several methods and various software tools are currently available to implement depth-averaged flows and model flow slides, debris flows and avalanches and reconstruct landslide dams (Hussin et al., 2012; Schraml et al., 2015; Delaney and Evans, 2015; Lin and Lin, 2015). We use Gerris because of its computational performance, flexibility, widespread use in fluid-flow mechanics, and its open-source policy (Popinet, 2003). Gerris can be employed to simulate avalanches and debris flows even in steep terrain due to a series of correction terms, which allow bypassing the almost-horizontal fluid table requirement by solving the shallow water equations in Cartesian coordinates (Hergarten and Robl, 2015). Correction terms for the acceleration of the fluid layer and the applied flow resistance law (Voellmy rheology) were tested and validated against Rapid Mass Movement Simulation (RAMMS), the leading software and industry standard for rapid mass movement simulation (e.g., Christen et al., 2010).

To reduce computation time, we discard landslides with volumes $<10^{5} \mathrm{~m}^{3}$. We assume sea level altitude (i.e., $0 \mathrm{~m}$ elevation) outside of Austria. This affects the flow simulation, and we thus discard manually the 77 landslides and lakes in contact with the DEM border. As such, there is an underestimated landslide dam density within $8 \mathrm{~km}$ of the DEM border. We model each landslide for a runout time of $6 \mathrm{~min}$. Due to high flow velocities, this time span is sufficiently long for the rock mass to deposit (i.e., for the landslide momentum to decrease to a small fraction of its maximum values).

After completing the simulation, the landslide mass is added to the DEM. The DEM is then filled using GRASS GIS, and the maximum landslide-dammed lake volume is computed by subtracting the original DEM from the filled DEM including the landslide mass.

\subsection{Geomorphometric parameters, damming percentage and indices of landslide dams}

We compare the geomorphometric parameters (Table 1) of our modeled landslide dams to those of landslide dams from existing inventories (Table 2). Except for Fan et al. (2012) and Tacconi Stefanelli et al. (2015), these studies focus on river-damming landslides only. Various indices have been developed to predict the ability of a landslide to dam a valley and the longevity of the dam. Those indices rely on simple parameters of the landslide, dam, lake and valley: the landslide dam volume $V_{\text {dam }}\left(\mathrm{m}^{3}\right)$ and height $H_{\text {dam }}(\mathrm{m})$, the landslide volume $V_{\text {landslide }}\left(\mathrm{m}^{3}\right)$, the lake volume $V_{\text {lake }}\left(\mathrm{m}^{3}\right)$, the upstream catchment area $A_{\mathrm{b}}\left(\mathrm{km}^{2}\right)$, and the local slope of the fluvial channel at the point of damming $S\left(\mathrm{~m} \mathrm{~m}^{-1}\right)$. They allow the estimation of the potential landslide damming risk.

To characterize our modeled dams, we use the landslide deposit volume $V_{\text {dep }}$ and the upstream catchment area of the dam-covered pixel with the highest flow accumulation $\left(A_{\mathrm{b}}\right)$. The slope $S$ is taken as the D8 slope (steepest outwards slope for a grid cell to one of its eight neighbors) at the same pixel location. Two metrics can be considered as proxies for $H_{\text {dam }}$ : the maximum height of the landslide deposit $H_{\mathrm{dep}}(\mathrm{m})$ and the maximum depth of the dammed lake $H_{\text {lake }}$ (m) (Fig. 2). Taking $H_{\text {lake }}$ as a proxy for $H_{\text {dam }}$ is possible because we use a filled, and hence depression-free, DEM, as a basis for landslide modeling. The maximum depth of the lake must thus be located close to the dam and represents the vertical distance from the lowest point in the dam cross section (Fig. 2b) to the lowest point in the valley longitudinal view (Fig. 2c). In contrast, $H_{\text {dep }}$ is located in the deposit but not necessarily close 
Table 1. Geomorphometric parameters mentioned in the article and their notation.

\begin{tabular}{ll}
\hline$V_{\text {landslide }}$ & Landslide volume \\
$V_{\text {dam }}^{*}$ & Dam volume \\
$V_{\text {dep }}$ & Volume of landslide deposit \\
$V_{\text {lake }}$ & Volume of landslide-dammed lake \\
$H_{\text {dam }}$ & Dam height (cf. Fig. 2) \\
$H_{\text {dep }}$ & Maximum landslide deposit height, "dam height proxy" (cf. Fig. 2) \\
$H_{\text {lake }}$ & Maximum dammed lake depth, "dam height proxy" (cf. Fig. 2) \\
$A_{\mathrm{b}}$ & Catchment area upstream of dam blockage \\
$S$ & Channel slope at the dam pixel of highest flow accumulation \\
$L_{\text {lake }}$ & Lake length (along the river) \\
$W_{\text {lake }}$ & Lake width (cross-sectional) \\
$V_{\mathrm{p} \text { lake }}$ & Predicted volume of landslide-dammed lake using easily calculable geomorphic parameters \\
\hline The extent of the sediments involved in the dam is hardly definable; thus the dam volume is not computed.
\end{tabular}

Table 2. Landslide dam and lake volume ranges from around the world compared to our generated landslide-dammed lakes. The Wenchuan landslide dams all originate from the 2008 Wenchuan earthquake. Numbers are approximates.

\begin{tabular}{|c|c|c|c|c|c|c|c|}
\hline Area and reference & $\begin{array}{c}\text { Min } \\
V_{\text {landslide }} \\
\text { or } V_{\text {dam }} \\
\left(\mathrm{m}^{3}\right)\end{array}$ & $\begin{array}{r}\text { Max } \\
V_{\text {landslide }} \\
\text { or } V_{\text {dam }} \\
\left(\mathrm{m}^{3}\right)\end{array}$ & $\begin{array}{c}\text { Min } \\
V_{\text {lake }} \\
\left(\mathrm{m}^{3}\right)\end{array}$ & $\begin{array}{l}\text { Max } \\
V_{\text {lake }} \\
\left(\mathrm{m}^{3}\right)\end{array}$ & $\begin{array}{r}\text { Min } \\
H_{\text {dam }} \\
(\mathrm{m})\end{array}$ & $\begin{array}{r}\text { Max } \\
H_{\text {dam }} \\
(\mathrm{m})\end{array}$ & $\begin{array}{r}\text { Damming } \\
\text { landslide } \\
\text { number }\end{array}$ \\
\hline Alps, Austria ${ }^{a}$ (this paper) & $7.7 \times 10^{4, b}$ & $9.9 \times 10^{7}$ & 0.0 & $7.9 \times 10^{7}$ & $0 \mid 3^{\mathrm{c}}$ & $75 \mid 155^{\mathrm{c}}$ & 1057 \\
\hline Alps, Austria (Dufresne et al., 2018) & $1.5 \times 10^{7}$ & $2.1 \times 10^{9}$ & 0.0 & $1.1 \times 10^{9}$ & 40 & 450 & 5 \\
\hline Apennines, Italy (Tacconi Stefanelli et al., 2016) & $3.0 \times 10^{4}$ & $1.1 \times 10^{8}$ & - & - & - & $>100$ & 300 \\
\hline Taiwan (Chen et al., 2014) & $6.0 \times 10^{2}$ & $5.0 \times 10^{8}$ & - & - & 3 & 300 & 64 \\
\hline Wenchuan, China (Fan et al., 2012) & - & $7.5 \times 10^{8}$ & $4.2 \times 10^{3}$ & $2.1 \times 10^{7, d}$ & 1 & 160 & 828 \\
\hline New Zealand (Korup, 2004) & $4.0 \times 10^{4}$ & $2.7 \times 10^{10}$ & $1.0 \times 10^{4}$ & $5.0 \times 10^{9}$ & 5 & 800 & 232 \\
\hline Japan (Korup, 2004) & $3.0 \times 10^{3}$ & $1.2 \times 10^{9}$ & $2.0 \times 10^{3}$ & $6.0 \times 10^{8}$ & - & - & \\
\hline USA (Korup, 2004) & $1.9 \times 10^{3}$ & $1.5 \times 10^{9}$ & $1.0 \times 10^{3}$ & $5.5 \times 10^{8}$ & - & - & \\
\hline Worldwide (Korup, 2004) & $4.3 \times 10^{3}$ & $1.3 \times 10^{9}$ & $2.0 \times 10^{3}$ & $4.0 \times 10^{9}$ & - & - & 184 \\
\hline Worldwide (Costa and Schuster, 1988) & $7.0 \times 10^{4}$ & $2.8 \times 10^{9}$ & $1.1 \times 10^{5}$ & $6.8 \times 10^{8}$ & 3 & 550 & 225 \\
\hline Worldwide (Fan et al., 2020) & $1.2 \times 10^{3}$ & $5.0 \times 10^{9}$ & 0.0 & $1.6 \times 10^{10, \mathrm{e}}$ & 2 & 1000 & $443^{\mathrm{f}}$ \\
\hline
\end{tabular}

${ }^{a}$ Modeled landslide dams and lakes. ${ }^{\mathrm{b}}$ The modeled landslides with volume below $10^{5} \mathrm{~m}^{3}$ were not computed. ${ }^{\mathrm{c}}$ The $H_{\text {dam }}$ proxies are written $H_{\text {lake }} \mid H_{\text {dep }}{ }^{\mathrm{d}}$ Except for the Tangjiashan landslide dam outlier, which impounded $3 \times 10^{8} \mathrm{~m}^{3}$ of water. ${ }^{\mathrm{e}}$ Usoi Dam, Sarez Lake, Tajikistan. ${ }^{\mathrm{f}}$ Number of database events with provided lake volume.
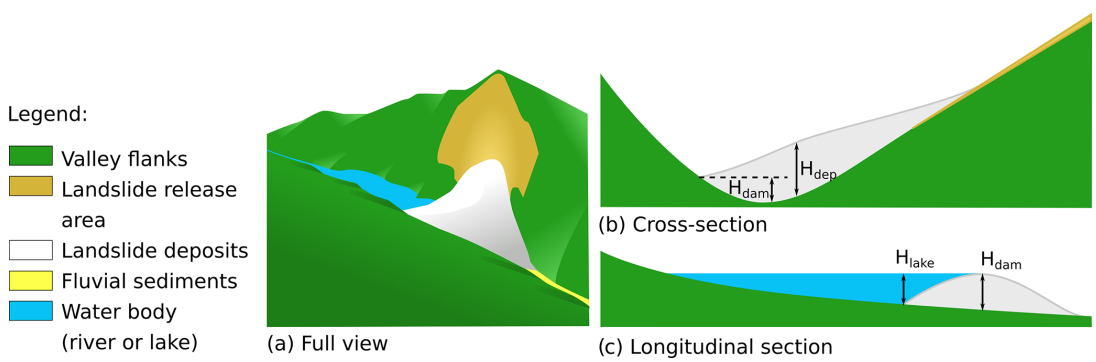

Figure 2. Definition of the heights $H_{\text {lake }}, H_{\text {dam }}$ and $H_{\text {dep }}$ in cross and longitudinal sections of a landslide dam. $H_{\text {lake }}$ and $H_{\text {dep }}$ can be easily computed, while $H_{\text {dam }}$ cannot. $H_{\text {lake }}$ : maximum lake depth, $H_{\text {dam }}$ : landslide dam height, $H_{\text {dep }}$ : maximum landslide deposit height.

to the dam (Fig. 2b). We assume the height metrics to follow the relation:

$H_{\text {lake }} \leq H_{\text {dam }} \leq H_{\text {dep }}$
Landslide dams are commonly classified in a binary and simple fashion between complete and partial blockages based on their planform geometry (Hermanns, 2013). Complete dam blockages are landslide deposits that fully obstructed the river flow and formed a lake. Partial dam block- 
ages are landslide deposits that encountered the riverbed and may have triggered an avulsion but did not completely impound the river. Complete blockages are much more dangerous than partial blockages and tend to trap sediments, while partial dams increase the river sediment load. Following Croissant et al. (2019), we assume that all of our modeled landslides, given their high volume, the initiating slope threshold and the self-similar structure of river networks, reach a riverbed, and thus qualify as either complete or partial blockages (Lucas et al., 2014). However, to avoid differentiating binarily between complete and partial dams through a visual inspection of thousands of modeled landslide dams, we compare $H_{\text {dep }}$ to $H_{\text {lake }}$ by using the $\frac{H_{\text {lake }}}{H_{\text {dep }}}$ ratio to create a continuous damming scale. If $\frac{H_{\text {lake }}}{H_{\text {dep }}}$ is small, then $H_{\text {dep }} \gg H_{\text {lake }}$, and the landslide likely did not fully obstruct the valley. However if $\frac{H_{\text {lake }}}{H_{\text {dep }}}$ is closer to $1, H_{\text {dep }} \approx H_{\text {lake }}$, and the landslide probably obstructed the valley.

In our study, we compare six obstruction and stability indices. Obstruction criteria have been developed to differentiate landslides leading to complete blockages from those leading to partial ones, while stability criteria aim to assess dam stability (e.g., the probability of the dam not failing) from simple geomorphometric parameters. Some indices can serve as both obstruction and stability criteria. The two indices that aim to classify the landslides according to their potential obstruction power and stability are the blockage index (BI) and the hydromorphological dam stability index (HDSI).

$\mathrm{BI}=\log \left(\frac{V_{\mathrm{dam}}}{A_{\mathrm{b}}}\right)$,

which divides landslide dam volume by the upstream catchment area, which was developed by Swanson et al. (1986) and then modified by Canuti et al. (1998), who replaced the landslide volume by landslide dam volume. Tacconi Stefanelli et al. (2016) introduced more recently the HDSI:

HDSI $=\log \left(\frac{V_{\text {landslide }}}{A_{\mathrm{b}} S}\right)$,

which differs from the BI by taking into account the channel slope. Both indices can be computed prior to landsliding (using the original version of the $\mathrm{BI}$ ).

Conversely, all other four indices use geomorphometric parameters linked to the dam or/and the lake, and thus they can only be used after landsliding to assert the dam stability. Casagli and Ermini (1999) proposed the impoundment index (II):

$\mathrm{II}=\log \left(\frac{V_{\mathrm{dam}}}{V_{\text {lake }}}\right)$,

which accounts for lake volume when estimating the landslide dam stability. The dimensionless blockage index (DBI)

$\mathrm{DBI}=\log \left(\frac{A_{\mathrm{b}} \cdot H_{\mathrm{dam}}}{V_{\mathrm{dam}}}\right)$, coined by Ermini and Casagli (2002), considers the dam height, allowing one to indirectly take into account the steepness of the dam flanks. Korup (2004) introduced two new indices also based on landslide dam height, the backstow index (Is) and the basin index (Ia):

Is $=\log \left(\frac{H_{\mathrm{dam}}^{3}}{V_{\text {lake }}}\right), \quad I a=\log \left(\frac{H_{\mathrm{dam}}^{2}}{A_{\mathrm{b}}}\right)$.

In contrast to the BI and HDSI, the stability indices (II, DBI, Is and Ia) use a non-dimensional combination of properties (volume per volume, or area per area), which should give more consistent results across different scales.

While the indices BI, II, and DBI use the volume of the dam instead of the total volume of the deposits, determining $V_{\text {dam }}$ automatically for large datasets is nontrivial. We therefore use $V_{\text {dep }}$ instead of $V_{\text {dam }}$ when computing the indices. This may lead to an overestimation of the volume if significant parts of the deposits do not reach the valley floor.

In turn, $V_{\text {dep }}$ is in general underestimated by our approach, mainly because the increase in volume by bulking via fragmentation and entrainment of further material is not taken into account. The Gerris solver even loses a small part of the volume at the tail of the landslide since layers below a given threshold thickness are disregarded. Thus, we have the following relationship: $V_{\text {dam }} \leq V_{\text {dep }}<V_{\text {landslide. However, the }}$ underestimation of $V_{\text {dep }}$ is only relevant if we consider the landslide dam in relation to the detached volume, which is not a subject of this study.

\section{Results}

We calculated landslide release areas with 100 landslide seeds per square kilometer and obtained 1057 release volumes larger than $10^{5} \mathrm{~m}^{3}$ in the Austrian Alps. We then used these release volumes and simulated the runout of landslides. We further investigated if landslide-dammed lakes are formed. In the following result sections, we describe the 1057 simulated landslides and landslide-dammed lakes: their spatial distribution, their geometric characteristics, and their associated stability and obstruction indices.

\subsection{Distribution of simulated landslides and landslide dams across the Austrian Alps}

The distribution of reported landslides in the Austrian Alps (Kuhn, visited 27 July 2020; Dufresne et al., 2018) is linked to topographic characteristics and geomorphological process domains (Fig. 3, green circles). Most of the landslides are located in the western part of the study region, within high topography with significant relief occupied by glaciers during the LGM. Modeled landslides (Fig. 3, white circles) and inventory landslides (Fig. 3, green circles) show similar spatial patterns, thus implying that the spatial heterogeneity in landslide occurrence arises from landscape characteristics. High 


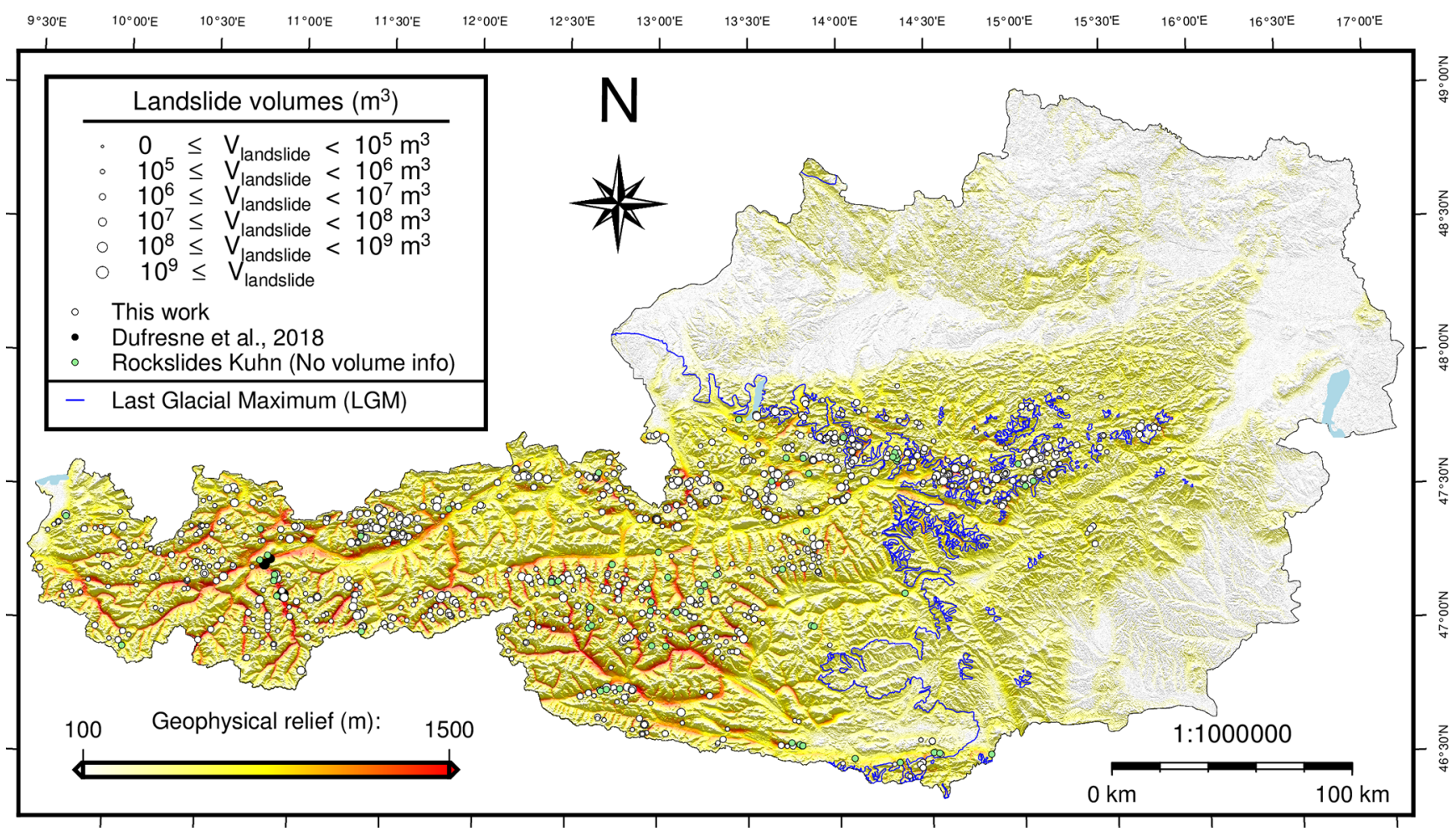

Figure 3. Spatial distribution of modeled and real-world landslides in the Austrian Alps plotted on geophysical relief. Landslide volume is reflected by the circle size. LGM extent is depicted by a blue line (Ehlers and Gibbard, 2004). The landslides marked by the green circles were compiled by Kuhn (visited 27 July 2020). Hillshades were computed from freely available lidar-based digital elevation model (DEM) of the Austrian Alps (Open Data Österreich, 2015).

local slope has a strong positive influence on simulated landslide density, while high landslide volume is rather driven by high relief.

Areas with high and low geophysical relief values spatially coincide with contrasting tectonic units (compare Figs. 3 and 4). This suggests that lithology exerts an important control on geophysical relief and hence landslide occurrence in the study region (Fig. 4). For example, major historical landslides are reported for the Northern Calcareous Alps (NCA) but not for the adjacent Greywacke Zone (the structural base of the NCA). This distribution is mimicked by our model due to the contrasting relief and slope characteristics of the two lithological units. Similarly, the prediction of many large landslides in the Ötztal-Bundschuh nappe system and the pre-Alpine basement (gneisses of the Tauern Window) is consistent with landslide occurrence in the landslide inventory (Kuhn, visited 27 July 2020), while a significantly lower tendency to landsliding is both modeled and reported in nearby tectonic units (e.g., Silvretta-Seckau or KoralpeWölz nappe system).

Glacial erosion is known to increase valley relief and to steepen valley flanks (Shuster et al., 2005; Valla et al., 2011). To further investigate the role of glacial imprint in preconditioning the occurrence of modeled landslides, we computed
Table 3. Landslide dam statistics for glacial and fluvial terrain.

\begin{tabular}{lrr}
\hline Imprint & Glacial & Fluvial \\
\hline Area $\left(\mathrm{km}^{2}\right)$ & 33751 & 45643 \\
Number of landslides & 999 & 58 \\
Landslide density $\left(\mathrm{km}^{-2}\right)$ & $3.0 \times 10^{-2}$ & $1.3 \times 10^{-3}$ \\
Mean deposit volume $\left(\mathrm{m}^{3}\right)$ & $8.6 \times 10^{6}$ & $3.1 \times 10^{6}$ \\
Mean lake volume $\left(\mathrm{m}^{3}\right)$ & $1.5 \times 10^{6}$ & $5.9 \times 10^{5}$ \\
Mean of the $H_{\text {lake }} / H_{\mathrm{dep}}$ & 0.26 & 0.39 \\
Mean of the $V_{\text {lake }} / V_{\mathrm{dep}}$ & 0.15 & 0.25 \\
\hline
\end{tabular}

landsliding densities and spatially distinguished $\frac{H_{\text {lake }}}{H_{\text {dep }}}$ ratios (Table 3). A total of $94.5 \%$ of the predicted landslide release areas are situated in glacially overprinted terrain. The glacial and fluvial landslide densities are $3.0 \times 10^{-2}$ and $1.3 \times 10^{-3}$ landslides per square kilometer, respectively. As expected, the disparities in landslide occurrence in glacial and fluvial terrain are even stronger for very large landslides. This is reflected in the mean volume that is about 2.8 times higher in the glacially overprinted domain than in the fluvial area. The large landslide volumes also result in larger lake volumes. On average, these are about 2.5 times higher in the glacially overprinted areas. In relation to the deposit volume, the lake 


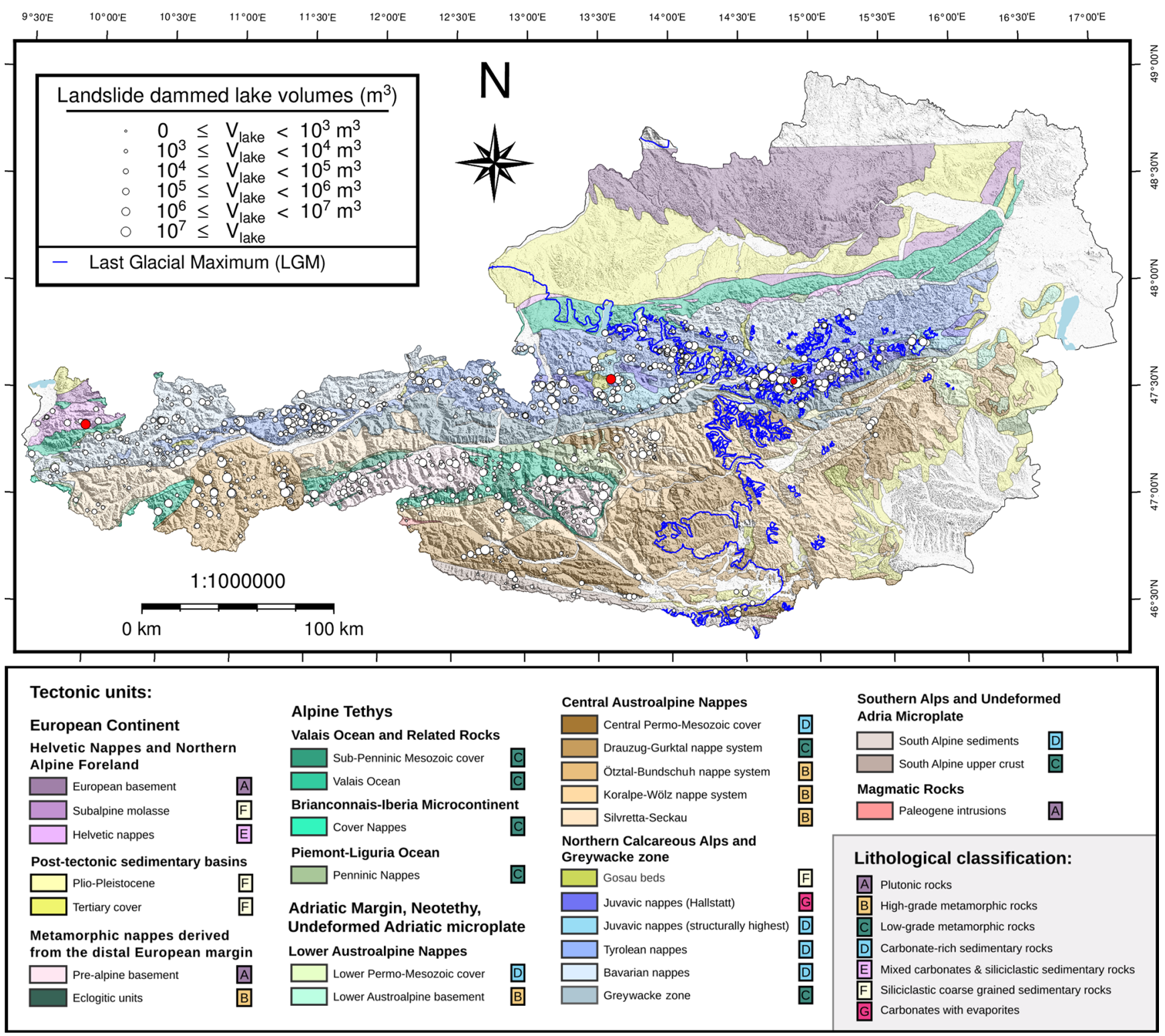

Figure 4. Spatial distribution of modeled landslide-dammed lakes in the Austrian Alps plotted on a map of tectonic units modified after Bousquet et al. (2012) (see also Schmid et al., 2004). The landslide-dammed lake volume is indicated by circle size. LGM extent is depicted by a blue line (Ehlers and Gibbard, 2004). Hillshades were computed from freely available lidar-based digital elevation model (DEM) of the Austrian Alps (Open Data Österreich, 2015). The three landslide-dammed lakes highlighted in red are mentioned in the text.

volume is, however, slightly smaller in the glacially overprinted areas, indicating that smaller lakes are dammed by a landslide deposit of a given volume. The same applies to lake depths and deposit depths. Both effects are probably a consequence of differences in glacial and fluvial valley geometry.

\subsection{Comparison of geomorphometric parameters}

We first compared deposit volumes $V_{\text {dep }}$, volumes of the dammed lakes $V_{\text {lake }}$, dam heights $H_{\text {lake }}$ and $H_{\text {dep }}$ of our modeled landslide dams to landslide inventories (Table 2). The modeled deposit volumes $V_{\text {dep }}$ range from the defined minimum of $10^{5} \mathrm{~m}^{3}$ to a maximum of almost $10^{8} \mathrm{~m}^{3}$, while the lake volumes $V_{\text {lake }}$ range from 0 to $7.9 \times 10^{7} \mathrm{~m}^{3}$. Both the $V_{\text {dep }}$ and the $V_{\text {lake }}$ maximums are 10 times smaller than the biggest dam and lake volume reported in Austria and between 10 and 100 times lower than the largest volumes found in Japan, the USA and New Zealand. This finding is not particularly surprising as the potential for very large landslides decreases through time after deglaciation (Hergarten, 2012). The simulated volume ranges are further in accordance with landslide dam and lake volumes found in the Apennines by 

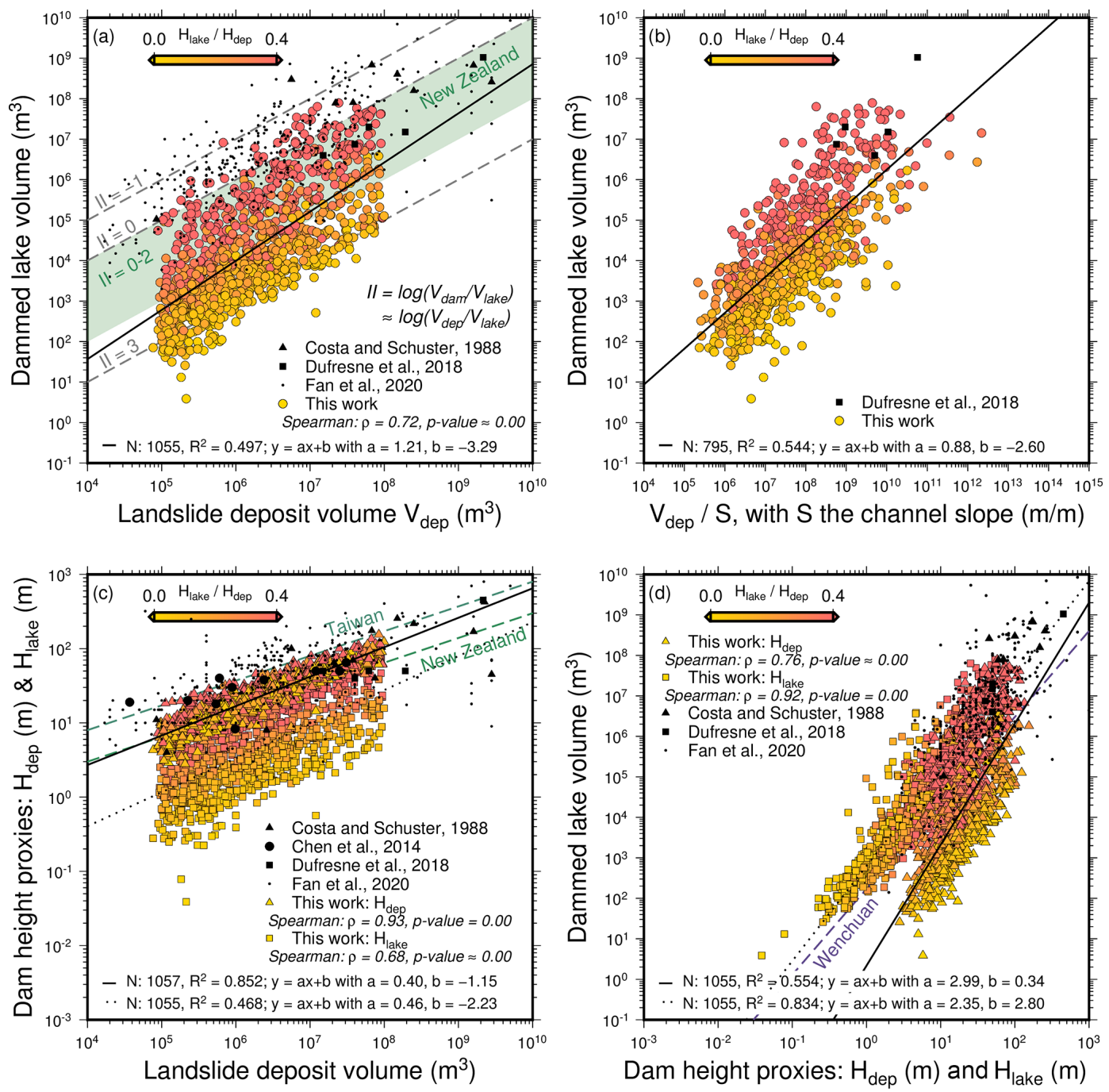

Figure 5. Bi-logarithmic diagrams of the landslide dam and lake metrics: (a) dammed lake volume in relation to landslide deposit volume (a.k.a. impoundment index) II, (b) dammed lake volume vs. channel slope, (c) landslide dam height proxies vs. landslide deposit volume, (d) landslide dam height proxies vs. dammed lake volume. $\frac{H_{\text {lake }}}{H_{\text {dep }}}$ is color-coded. $a$ and $b$ represent slope and intercept of the fitted power laws, respectively. $N$ varies as two landslides did not dam a lake and channel slopes equal to zero were not considered. New Zealand data from Korup (2004), Taiwan data from Chen et al. (2014), Wenchuan data from Fan et al. (2012), and worldwide data from Fan et al. (2020).

Tacconi Stefanelli et al. (2016). The maximum of our $H_{\text {lake }}$ proxy for landslide dam heights is 6 times lower than reported for Austria, 10 times lower than in New Zealand, and 2 times lower than those from Wenchuan and Italy. However, the maximum of our $H_{\mathrm{dep}}$ proxy is similar to those from Wenchuan and Italy.

The introduced geomorphometric parameters show distinct relationships (Fig. 5), which have also been identified in inventories. We carried out Spearman correlations and fitted power-law relations between the considered properties. Although the modeled deposit and lake volumes are strongly correlated, with a Spearman's $\rho$ of 0.72 (Fig. 5a), the deposit volume can only explain a part of the variability in the lake volume dataset, with a coefficient of determination $\left(R^{2}\right)$ of 0.497. The II, the logarithm of $\frac{V_{\text {dep }}}{V_{\text {lake }}}$, of the modeled landslide dams stretches from 0 to 3 , while values from literature are mostly found between 0 and 2 in Austria (Dufresne et al., 2018) and New Zealand (Korup, 2004) and between -1 and 1 for the largest dams worldwide (Costa and Schuster, 1988; Fan et al., 2020) (Fig. 5a). The height ratio $\frac{H_{\text {lake }}}{H_{\text {dep }}}$ of our modeled landslides is strongly correlated to the II (color coding in Fig. 5), and field observations of landslide dams are found among the simulated results with high height ratios. In this way, $\frac{H_{\text {lake }}}{H_{\text {dep }}}$ is linked to $\frac{V_{\text {dep }}}{V_{\text {lake }}}$, and both ratios are indicators for efficient damming, i.e., relatively small landslides damming relatively large lakes. Power-law fitting shows that lake volume increases nonlinearly with deposit volume for all events and that the mean II decreases from 2.2 to 1.6 over 
the considered volume range. For damming events with the highest lake volumes relative to deposit volumes, i.e., efficient damming, however, lake volume increases linearly with deposit volume.

Lake volume exhibits an inverse relationship with channel slope. Combining the channel slope (Fig. 5b) with deposit volume explains more of the lake volume variability $\left(R^{2}=\right.$ $\left.0.544>R^{2}=0.497\right)$.

The dam height proxies $H_{\text {dep }}$ and $H_{\text {lake }}$ scale nonlinearly with the deposit volume (Fig. 5c), reproducing reported relationships (Costa and Schuster, 1988; Chen et al., 2014; Dufresne et al., 2018). The deposit height correlates strongly $(\rho=0.93)$ and presents less dispersion than the lake depth $(\rho=0.68)$. Similar to the deposit to lake volume relation, the lake depth fits the literature data best for high $\frac{H_{\text {lake }}}{H_{\text {dep }}}$ ratios. The power law exponents $(\alpha=0.40, \alpha=0.46)$ are close to each other. Landslides of volumes smaller than $10^{6} \mathrm{~m}^{3}$ show a power law of exponent $\alpha=0.448$ when fitted separately, while landslides with volumes larger than $10^{7} \mathrm{~m}^{3}$ give a power law of exponent $\alpha=0.325$.

The lake volume scales nonlinearly with the dam height proxies $H_{\text {dep }}$ and $H_{\text {lake }}$ (Fig. 5d). The situation is reversed to Fig. 5c, such that the lake depth correlates strongly with the lake volume $(\rho=0.92)$, which conforms to the trends in inventories. The deposit height shows a weaker correlation with lake volume $(\rho=0.76)$. In both cases, dams and lakes with similar $H_{\text {lake }}$ and $H_{\text {dep }}$, thus high $\frac{H_{\text {lake }}}{H_{\text {dep }}}$ ratios, match the field observations better.

The lake depth scales nonlinearly with the deposit height (Fig. A2), with similar coefficients and behavior as found with the lake and deposit volumes.

\subsection{Obstruction and stability indices}

We apply six obstruction and stability indices to our modeling results (Fig. 6). Korup (2004) and Tacconi Stefanelli et al. (2015) determined index thresholds, which separate their landslide dams into different obstruction and stability classes:

- No data indicates that no partial or complete landslide dams were observed.

- Partial indicates that the landslides only partly obstructed the riverbed to form a partial dam.

- (Complete,) Unstable indicates that the landslides fully obstructed the riverbed, but the formed dams breached catastrophically.

- (Complete, ) Stable indicates that the landslides fully obstructed the riverbed, and the formed dams did not experience any catastrophic failure. However, they may have disappeared by sediment infilling or gradual incision.
- Undefined indicates that the landslide dams are either partial, (completely) unstable or (completely) stable.

We compared our modeled dams and related lakes to their obstruction and stability classes (Fig. 6). Our dams fall into different fields, depending on the applied indices.

For the BI, Korup (2004) and Tacconi Stefanelli et al. (2015) studied the Southern Alps, New Zealand, and Apennines, Italy, respectively, and found different limits for the stability classes. This affects the stability classification of our dams (Fig. 6a). Many modeled dams are considered stable in the Apennines classification scheme, while none are stable according to the New Zealand scheme. The relation between BI and $\frac{H_{\text {lake }}}{H_{\text {dep }}}$ is ambiguous, but we observe that $\frac{H_{\text {lake }}}{H_{\text {dep }}}$ and $V_{\text {lake }}$ are positively correlated with catchment area $A_{\mathrm{b}}$.

The HDSI, originally defined for the Apennines (Tacconi Stefanelli et al., 2015), presents no obvious relation to the $\frac{H_{\text {lake }}}{H_{\text {dep }}}$ ratio. Our data range is more extended than determined for the Apennines (Fig. 6b). Again, a minority of dams are considered stable in the HDSI, while the majority fall into the undefined class, and a considerable fraction is classified as unstable or partially stable.

For the II (Fig. 6c), the majority of landslides, in particular those with small lake volumes, fall into the stable class as determined for the Southern Alps, with the tendency of stability decreasing with lake volume. Further, the II displays a strong positive correlation with the $\frac{H_{\text {lake }}}{H_{\text {dep }}}$ ratio and lake volumes.

For the DBI, the situation is similar to the BI, with mountain range-dependent class definitions and no overlap between the stable classes (Fig. 6d). Accordingly, our modeled dams can either be classified as stable or undefined or even undefined or unstable. The DBI shows a strong positive correlation with the $\frac{H_{\text {lake }}}{H_{\text {dep }}}$ ratios. High lake volumes tend to gather around medium DBI values.

According to the Is classification from the Southern Alps, our modeled lakes are either classified as undefined or unstable, with no lakes in the stable class. Further, the Is presents no correlation with the $\frac{H_{\text {lake }}}{H_{\text {dep }}}$ ratio (Fig. 6e).

The Ia classes determined in the Southern Alps (Fig. 6f) lead to our modeled lakes being classified as either undefined or unstable and far from stable. The relations between Ia and $\frac{H_{\text {lake }}}{H_{\text {dep }}}$ ratio and lake volumes are ambiguous.

Summing up, the predictions on the stability of our modeled landslide dams vary strongly depending on the indices and thresholds chosen (e.g., II, Ia). Further, the indices display changing correlations with the $\frac{H_{\text {lake }}}{H_{\text {dep }}}$ ratio, a proxy for efficient damming. While the II and DBI both link low $\frac{H_{\text {lake }}}{H_{\text {dep }}}$ ratios with high stability results, the other four indices show no obvious relationship. The $\frac{H_{\text {lake }}}{H_{\text {dep }}}$ ratio is correlated positively with the catchment area $A_{\mathrm{b}}$, the lake volume $V_{\text {lake }}$ and height $H_{\text {lake }}$, with higher values for bigger catchments, but it does not display any obvious correlation with the deposit volumes $V_{\text {dep }}$ and their slope $V_{\text {dep }} / S$. 

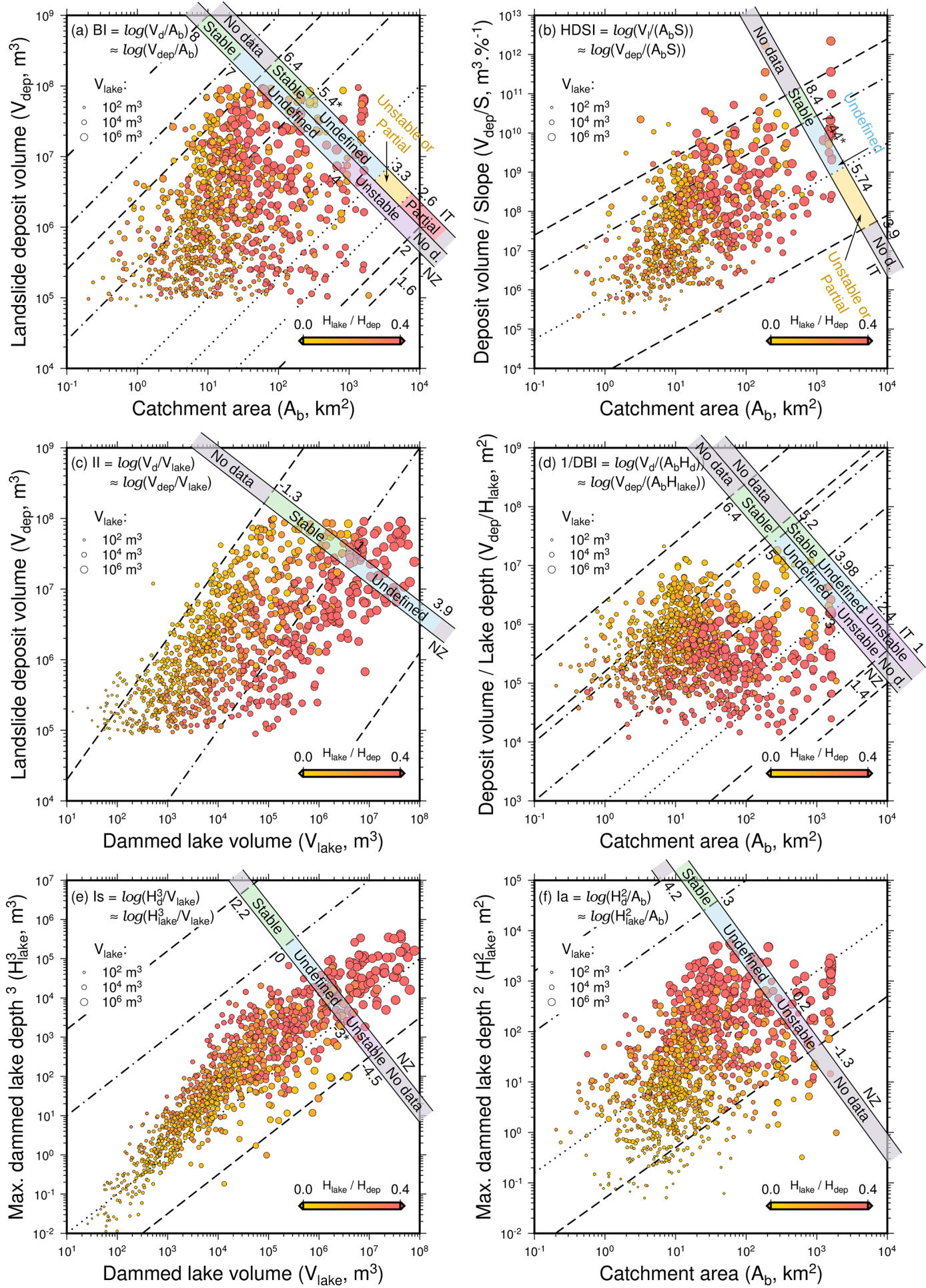

Figure 6. Bi-logarithmic diagrams of landslide dam classification according to two obstruction and stability indices: (a) the blockage index (BI) and (b) the hydromorphological dam stability index (HDSI). Also according to four stability indices: (c) the impoundment index (II), (d) the dimensionless blockage index (DBI), (e) the backstow index (Is) and (f) the basin index (Ia). Circle color represents $\frac{H_{\text {lake }}}{H_{\text {dep }}}$, and circle size depicts lake volume. The obstruction and stability ranges from literature are indicated by scales, with the threshold values annotated. Threshold lines are dashed for "No Data", dot-dashed for "Stable" and dotted for "Unstable". New Zealand data (Korup, 2004) are indicated by NZ and Apennines data from Italy (Tacconi Stefanelli et al., 2016) by IT. The threshold values marked with an asterisk present a few outliers in the reported literature data. The cluster of values with a catchment area of $10^{3} \mathrm{~km}^{2}$ is located in the same area in the Gesäuse mountain range, in the Enns catchment. 
There are no big trends linked to tectonic units in the indices plots (Fig. A3). Tectonic units are homogeneously distributed in the BI plot, except for the Juvavic nappes (Hallstatt), which present slightly higher BI values, showing on average bigger lake volumes than the other units for the same landslide volumes. There is also no obvious glacial control on the stability of landslide dams (Fig. A4). There seems to be a higher concentration of unstable landslide dams in the fluvial domain (BI, DBI, Is and HDSI).

\section{Discussion}

We simulated the formation of 1057 landslide dams and lakes in Austria. In the following, we discuss possible controls on the distribution of modeled dams and lakes and evaluate similarities with and differences to field observations. Finally, we provide information on model limitations.

\subsection{Correlations of dam and lake metrics}

Modeled dam and lake volumes show similar but stronger relationships than those derived from inventories and exhibit an extended value range not observed in the field (Fig. 5). We find a clear correlation between landslide deposit volumes and dammed lake volumes in our dataset, with a Spearman's $\rho$ of 0.72 . Landslide dam height proxies and landslide dam and lake volumes show similarly high correlations. In contrast, Korup (2004) reports a weaker correlation between landslide dam volumes and dammed lake volumes in New Zealand, indicated by a Spearman's $\rho$ of 0.558 , and in the landslide dam datasets of Costa and Schuster (1991), Perrin and Hancox (1992), and Hancox et al. (1997). In any case, the range of our model results in almost exactly parallel uniform II values (Fig. 5a), which indicates that a universal dependence of lake volumes on deposit volumes exists both in our model and in the real world.

For a given landslide volume, modeled lake volumes exhibit a bigger variability than reported in the literature (Fig. 5a). In our model, large landslides often impound relatively small lakes, leading to volume ratios $\left(V_{\text {dep }} / V_{\text {lake }}\right)$ up to 1 order of magnitude larger than in inventories, in conjunction with low $\frac{H_{\text {lake }}}{H_{\text {dep }}}$ ratios. We relate this variability to the position of the landslide deposit in the valley. Landslides not reaching the main stream or depositing on the valley flank may only produce small lakes and hence present a low $\frac{H_{\text {lake }}}{H_{\text {dep }}}$, while landslides depositing homogeneously across the riverbed dam larger lakes and have a higher $\frac{H_{\text {lake }}}{H_{\text {dep }}}$ ratio. In contrast to our model, inventories predominantly report efficient damming in main valleys (i.e., valleys with distinct valley bottom and two flanks), while small lakes dammed by large landslides outside of clear valley structures (e.g., on valley flanks) are missed.

The negative correlation of lake volume with channel slope (Fig. 5b) can be expected as larger lakes form in higher- order sections of the drainage network where channel slopes are lower.

Modeled deposit (or the lake) height decreases with increasing volume for large landslides, as found by Larsen et al. (2010), while small modeled landslides display an opposite scaling. We observe that $H_{\text {dep }} \sim V_{\text {dep }}^{0.40}$ and $H_{\text {lake }} \sim$ $V$ dep $^{0.46}$ (Fig. 5c, black lines). As the exponent is greater than $\frac{1}{3}$ in both relations, the deposits become relatively thicker and the lakes become relatively deeper with increasing landslide volume. In the real world, landslide deposits reportedly show the opposite behavior. Larsen et al. (2010) obtained $V_{\text {landslide }} \sim A^{1.40}$ for both the scar area and the deposit area, which implies $H_{\text {landslide }} \sim A^{0.4}$ for the mean thickness. This thus gives $H_{\text {landslide }} \sim V_{\text {landslide }}^{(0.4 / 1.4)}=V_{\text {landslide }}^{0.29}$, with the depth-volume scaling exponent lower than $\frac{1}{3}$, implying that large deposits are relatively thinner than small deposits. However, thickening of deposits and deepening of lakes with increasing landslide volumes is obtained when a power law is fitted to all model data. For the largest lake depths and dam heights relative to the deposit volumes, i.e., efficient damming, our model results mirror the inventories Fig. 5c). In contrast, thickening and deepening in our model is even more pronounced for the deposits and lakes with the smallest heights and depths. Consequently, the power-law relationship between $V_{\text {dep }}$ and $H_{\text {dep }}$ depends on $V_{\text {dep }}$. Landslides of volumes $>10^{6} \mathrm{~m}^{3}$ show a power-law exponent of 0.448 , while landslides with volumes $>10^{7} \mathrm{~m}^{3}$ give a power-law exponent of 0.325 (Fig. 5c). A similar relation can be observed between the lake depths and volumes (Fig. A2). This again indicates a change in deposit geometry with $V_{\text {dep }}$ controlling the link between $V_{\text {dep }}$ and $H_{\text {dep }}$, which, upon constant model rheology, can only be attributed to valley shape.

\subsection{Impact of glacial imprint on simulated landsliding and dam formation}

Glacially imprinted terrain hosts larger landslide and lake volumes but lower $\frac{H_{\text {lake }}}{H_{\mathrm{dep}}}$ ratios. This can be explained by the typical glacial topography. Glacial landscapes are characterized by overdeepened, U-shaped troughs with steep flanks, cirques, and steep arêtes and ridges that have often higher slopes than fluvial headwaters and hillslopes (Agassiz and Bettannier, 1840; Penck, 1905; Anderson et al., 2006). The formerly glaciated areas of the Austrian Alps present the highest mean elevations, relief, slopes and uplift rates, and almost all modeled landslides, which also applies to the inventory (Fig. 3). Further, adjustment of glacial landscapes to deglaciation has been suggested to lead to an increase in hillslope processes (Church and Ryder, 1972; Crest et al., 2017; Jiao et al., 2018). This fits our distribution of landslides and release volumes. The landslides in glacial terrain are 2.8 times more voluminous, dam 2.5 times bigger lakes but lead to 1.5 times lower $\frac{H_{\text {lake }}}{H_{\text {dep }}}$ ratios. We again attribute these differences to valley shape. The wide valley floors in 
glaciated areas demand for higher landslide volumes to dam the entire valley. Thus partial damming is more common, which leads to lower height ratios. On average, the much higher release volumes in glacial landscapes almost compensate for the wide valley floors, which results in only slightly lower height ratios. This in conjunction with flat and wide valley floors leads to the formation of bigger but shallower lakes.

\subsection{Most efficient simulated lake damming in Austria}

In our model, the most efficient damming, i.e., dammed lakes with exceptionally large volumes relative to the deposit volumes, occurs in several tectonic units across Austria, all characterized by exceptional valley relief. We highlight three examples found in different structural units: Gosau group, Helvetic nappes, and Tyrolean nappes (Fig. 4, red dots). In our simulations, large lakes are formed by landslides damming relatively narrow valleys downstream of wider and flatter valley sections. In the Gosau group, a landslide of $6.6 \times 10^{6} \mathrm{~m}^{3}$ dams the Gosaubach downstream of the flat and wide Gosau valley, where a lake of $3.4 \times 10^{7} \mathrm{~m}^{3}$ forms (height ratio $=0.73$ ). In the Helvetic nappes, a landslide of $4.3 \times 10^{7} \mathrm{~m}^{3}$ dams the Bregenzer Ache, leading to a lake of $5.7 \times 10^{7} \mathrm{~m}^{3}$ (height ratio $=0.65$ ). A region prone to several big landslide-induced lakes in our simulations is the Gesäuse range, which is located in the Northern Calcareous Alps. This area combines very steep valley flanks with a narrow valley floor. Consequently, the region generally presents relatively high height ratios mostly ranging from 0.38 to 0.94 . The largest lake reaches a volume of $3.9 \times 10^{7} \mathrm{~m}^{3}$ (height ratio $=0.56$ ) due to valley widening upstream of the dammed gorge section of the Enns River (landslide dam volume $=5.9 \times 10^{7} \mathrm{~m}^{3}$ ). In the same area, another landslide of $2.4 \times 10^{7} \mathrm{~m}^{3}$ creates two lakes totaling $7.9 \times 10^{7} \mathrm{~m}^{3}$ on the Erzbach (height ratio $=0.94$ ). These three examples highlight the role of valley geometry in controlling the efficiency of damming. Further, our examples suggest that a change of tectonic units along a river, with a narrow section at the damming location and a wider section upstream, favors efficient damming and the formation of very large lakes. In the Austrian Alps such settings occur in the Northern Calcareous Alps (e.g., Enns River, Salzach River).

\subsection{Predicting the volume of landslide-dammed lakes}

In our model results, we find a relationship between $V_{\text {dep }}(=$ $V_{\text {landslide }}$ ) and $V_{\text {lake }}$ (Fig. 5a), as well as between $V_{\text {lake }}$ and upstream drainage area $A_{\mathrm{b}}$ at the location of damming, which we use to compute a predicted lake volume $V_{\mathrm{p}}$ lake, such that

$V_{\text {lake }} \sim V_{\mathrm{p} \text { lake }}=\alpha \cdot V_{\text {landslide }}^{0.98} \cdot A_{\mathrm{b}}^{0.92} \times 10^{-6}$,

with $\alpha=0.003$ and $A_{\mathrm{b}}$ in square meters.

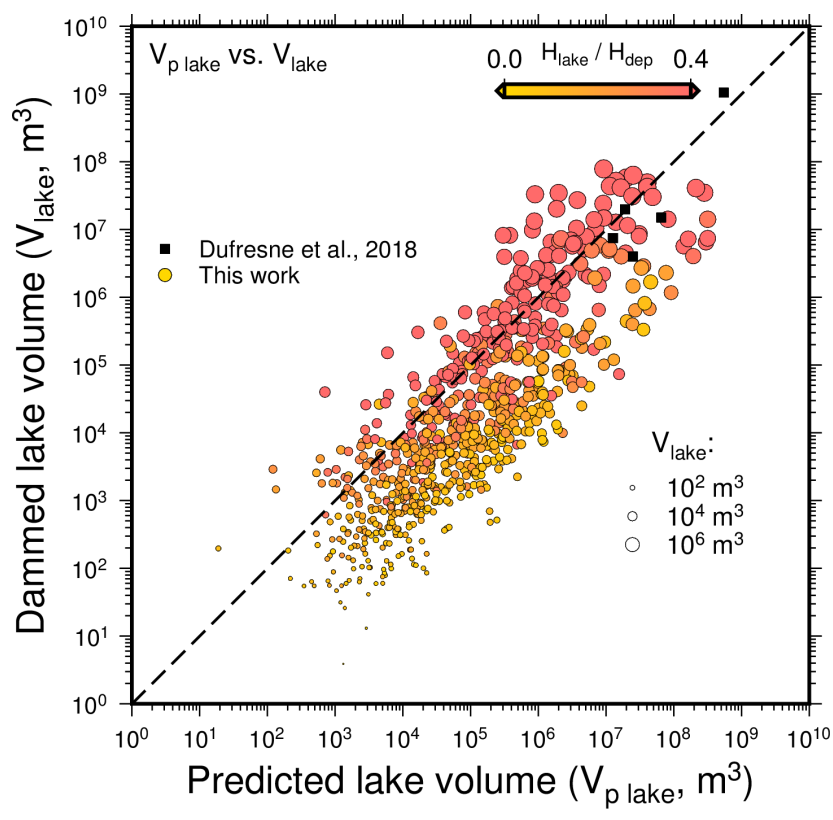

Figure 7. Bi-logarithmic diagram showing predicted ( $V_{\mathrm{p} \text { lake }}$, Eq. 7$)$ vs. modeled $\left(V_{\text {lake }}\right)$ landslide-dammed lake volume. Circle size represents dammed lake volume, and circle color indicates height ratio. $1: 1$ relation is depicted by dashed line.

The existence of such a relationship can be theoretically explained by the influence of the drainage system on valley morphology. The volume of the lake depends on the volume of the landslide and the valley shape. The width, depth (and hence height of the valley flanks) and the longitudinal slope of the valley depend on the upstream drainage area (Flint, 1974; Whitbread et al., 2015), as does the height of the dam for a given landslide volume. The relationship also applies to real-world data and allows the prediction of potential $V_{\text {lake }}$ only from $V_{\text {landslide }}$ and $A_{\mathrm{b}}$ (Fig. 7), two metrics that can be easily obtained from DEMs and landslide inventories. Further, the relationship facilitates the development of damming scenarios with little effort by computing potential lake volumes from different potential landslide volumes. The model explains a larger part of the variation in $V_{\text {lake }}$ $\left(R^{2}=0.687\right)$ than $V_{\text {dep }}$ or $A_{\mathrm{b}}$ alone (respectively $R^{2}=0.497$ and $\left.R^{2}=0.394\right)$. Further, the model can be approximated reasonably well by assuming a linear influence of $V_{\text {landslide }}$ and $A_{\mathrm{b}}$. The additional variation of $V_{\text {lake }}$ present in the data again depends on valley and hence deposit geometry, as indicated by the color-coded $\frac{H_{\text {lake }}}{H_{\text {dep }}}$ ratio in (Fig. 7). The prediction works best for efficient damming indicated by high $\frac{H_{\text {lake }}}{H_{\text {dep }}}$.

\subsection{Obstruction and stability indices}

The obstruction and stability indices calculated from our 1057 simulated landslide dams do not provide consistent assessments. This finding corroborates the results of Dufresne 
et al. (2018), who also found the indices BI, II, DBI, Is, Ia and HDSI inconclusive in the Eastern Alps.

However, since our model cannot directly predict the stability of the modeled landslide dams, we can only conclude that they are inconsistent but cannot rate the performance of the indices in the Austrian Alps. The II and DBI are the only two indices showing a relationship with the metrics of our modeled landslides, represented by $\frac{H_{\text {lake }}}{H_{\text {dep }}}$ in Fig. 6. For these indices, stability decreases with increasing $\frac{H_{\text {lake }}}{H_{\text {dep }}}$, as well as increasing catchment area, lake volume and depth. All other investigated indices seem to depend on regionally constrained stability classes and are thus not easily transferable to the Austrian Alps.

\subsection{Limits and amelioration of the method}

\subsubsection{Differences between simulations and inventories}

Part of the discrepancies between modeled and real-world metrics (e.g., landslide and lake volume) are likely explained by topographic differences between our study area (Austrian Alps) and other mountain ranges we used for comparison. Variations in the topographic expression are related to lithological heterogeneity (contrasts in rock mass strength), climatic conditioning (e.g., fluvial versus glacial, rates of precipitation) and tectonic forcing (variations in timing and rates of uplift). However, the differences between modeled and real-world metrics may also be a consequence of uncertainties in field measurements and oversimplifications in our model.

The accuracy of field data is limited by, among other effects, measurement uncertainties and systematic underrepresentation of small landslide dams. In many cases, remnants of landslide dams and lakes need to be interpreted, hampering the assessment of their size and extent. In addition, even if dams and lakes are preserved, the topography prior to landsliding often remains unknown. This effect is also mentioned by Korup (2004), who suggests that uncertainties in the estimation of landslide dam heights are responsible for the differences between field and model results. Furthermore, large landslides may only create small dams and shallow lakes, for example when they partially block the valley floor or impound a small creek in relatively steep terrain. Since small dams get eroded in a short time and shallow ponds of water fill with sediments very quickly, they often remain undiscovered in the field. Yet they can be simulated, leading to a wider range of modeled landslide dams. These small dams are not considered in the inventories of Fan et al. (2020), Dufresne et al. (2018), Korup (2004), and Costa and Schuster (1988). The typical dammed lake size raising interest beyond the landslide itself seems to differ between massifs. In the case of the Alps, dams are reported for II $<2$ (Fig. 5a).

In contrast to field measurements, geomorphometric parameters obtained in a modeling study are highly precise, but assumptions and approximations made along the numerical process chain introduce uncertainty to the results. As an example, we assume that lakes are filled to the brim, which might not always happen in reality, due to loss of water via groundwater flow through the landslide deposits or riverbed substrate (Snyder and Brownell, 1996).

\subsubsection{Uniform slope stability threshold}

The determination of landslide release areas is crucial for our study. We employ an empirical model (Hergarten, 2012) that relies on the assumption of spatially uniform slope stability thresholds. We use the same slope stability thresholds for the entire Austrian Alps, which represents a distinct simplification. The study area hosts rocks that form differently steep landscapes, are characterized by potentially different rock mass strengths and therefore are likely to resist differently to erosive surface processes. It is generally assumed that rock mass strength exerts some control on slope stability thresholds on bedrock slopes (Montgomery, 2001), which host the landslide release areas of the study region. However, this assumption has rarely been tested (Goudie, 2016) and can hardly explain the persistence of "over-steepened" valley flanks (Fernández et al., 2008) abundantly observed in glacially imprinted mid-latitude mountain ranges such as the Austrian Alps. In addition to rock type, a variety of other parameters, including weathering, tectonic stresses, type and orientation of discontinuities at different scales, influence rock mass strength (Augustinus, 1995).

However, this study focuses on regional patterns of landslide dams and lakes, and to our knowledge, no stability thresholds based on lithology or rock mass strength are available at this scale. Moreover, the model used here to determine landslide release areas (Hergarten, 2012) is so far the only model which is able to reproduce the typical power-law scaling of landslides (Fig. A5; Tebbens, 2020). This scaling is not altered much by shifting the stability thresholds within a realistic slope range where rapid mass movements originate in mountainous areas (Hergarten, 2012). Furthermore, the power-law scaling applies to rockfalls as well as to slides (Brunetti et al., 2009). As an advantage, taking the same thresholds for the whole mountain range allows for a simple model, where topography is the main control of landsliding. Indeed, the similarities between our results (Fig. 3) and inventory events imply that topography is indeed the main control on the spatial distribution and scaling of landslides and landslide-dammed lakes on this large scale of analysis.

\subsubsection{Lack of temporal constraints}

While the employed landslide release area model (Hergarten, 2012) can provide release areas and related volumes, which cluster in the same regions as the events recorded in landslide inventories, and which are consistent with power-law scaling of landslides observed in nature, the model cannot 
predict timing or probability of failure of individual events. While such information would be of great value for natural hazard mitigation, neither field data as input parameters nor any of the existing state-of-the-art models can currently provide such an information at the scale of an entire mountain range. Hence, modeling results cannot be interpreted in terms of landslide-damming probability, nor in terms of return periods, which is also far beyond the scope of this study. As a consequence, we use the term landslide "densities" for the number of landslides per area to avoid misinterpretations in terms of time dependence (e.g., probability of occurrence or recurrence interval).

\subsubsection{Rheological model}

The determination of the rheology of the moving landslide mass is crucial as the chosen flow resistance law (i.e., Voellmy rheology), and the applied parameters control the runout distance and the landslide dam geometry (Hungr, 2011). Landslide rheology may be controlled by lithology but may also vary spatially within a single landslide event, when different rock types are involved, or temporally, when a change in physical conditions (e.g., water content, path material) happens during the landslide runout (Hungr and Evans, 2004; Aaron and McDougall, 2019). For individual landslides, rheology parameters are in general determined by a back analysis of the event itself or events in the same region (Mergili et al., 2020). However, considering this level of detail for an entire mountain range would require backanalyzing a large number of landsliding events, which is far beyond the capabilities of this investigation.

Runout simulations are type-specific (Hungr et al., 2001; Dorren, 2003), but most of the rockfalls with $V>10^{5} \mathrm{~m}^{3}$ have a long runout (i.e., termed "rock avalanche") and can be simulated accurately if the correct rheology model is used (Körner, 1976). Here, we apply the Voellmy flow resistance law with the parameter set determined by a back analysis of the well-documented Val Pola landslide (Sanne, 2015) to all simulated landslides of this study. As a benefit of a uniform parameter set, we can directly compare dam geometries and related lakes across the Austrian Alps and attribute spatial variations to topography. To explore the influence of the two Voellmy parameters $\xi$ and $\mu$ on dam height, we performed a parameter study starting with the $\xi / \mu$ parameter set originally determined by Sanne (2015) (Fig. A1). The parameter study at 10 different locations shows that dam height increases with $\mu$. While increasing $\xi$ causes an increase in landslide velocity and runout distance, we only observe a slight negative impact on dam height. As long as the parameter sets are suitable to describe the behavior of large landslides in alpine regions (and not mudflows or lahars with a completely different rheology unsuitable to form major dams), our parameter study implies that different rheologies will change the dam geometry to some extent but will not necessarily lead to a statistically consistent change in lake depth and volume (Fig. A1).

\section{Conclusions}

We modeled landslides, landslide dams and dammed lakes in Austria with a new approach that combines a probabilistic approach to determine landslide release areas and a fluid dynamic model to compute landslide runouts. Based on our results, we explored relationships between properties of landslides, landslide dams and lakes, and the drainage area and valley shape.

- The resulting landslides predominantly occur in steep alpine terrain and spatially coincide with historical events reported in inventories.

- Valley geometry and the drainage system control the efficiency of damming, i.e., small landslide dams impounding large lakes. Consequently, dam and lake metrics differ for glacial and fluvial terrain.

- The modeled range in damming efficiency is much larger than in inventories, where mostly events of efficient damming are reported. In our study, scaling of landslide, dam and lake metrics differs for low and high damming efficiency.

- We provide a new relationship to estimate lake volume only from upstream drainage area and landslide volume. These two parameters explain more than $60 \%$ of lake volume variability.

- Common stability and obstruction indices do not provide concise information on dam persistence. While the impoundment index (II) and the dimensionless blockage index (DBI) seem to work relatively well, the other tested indices give inconsistent results, with stability classes strongly varying between regions.

Our modeling results suggest that events with a low damming efficiency are much more frequent than represented in inventories and that they may exhibit a different scaling of landslide and lake metrics. We suspect that such events are also common in the real world, and high-efficiency events are over-represented in inventories. We thus suggest that a focus is put on low-efficiency damming in the compilation of future landslide databases.

From a hazard point of view, our study statistically models the initial steps of a natural hazard cascade. A logical extension of this work to be covered in future research would thus be a dam-breaching model (Fan et al., 2019) to simulate the longevity and stability, as well as the failure mode of the created dams. 


\section{Appendix A}
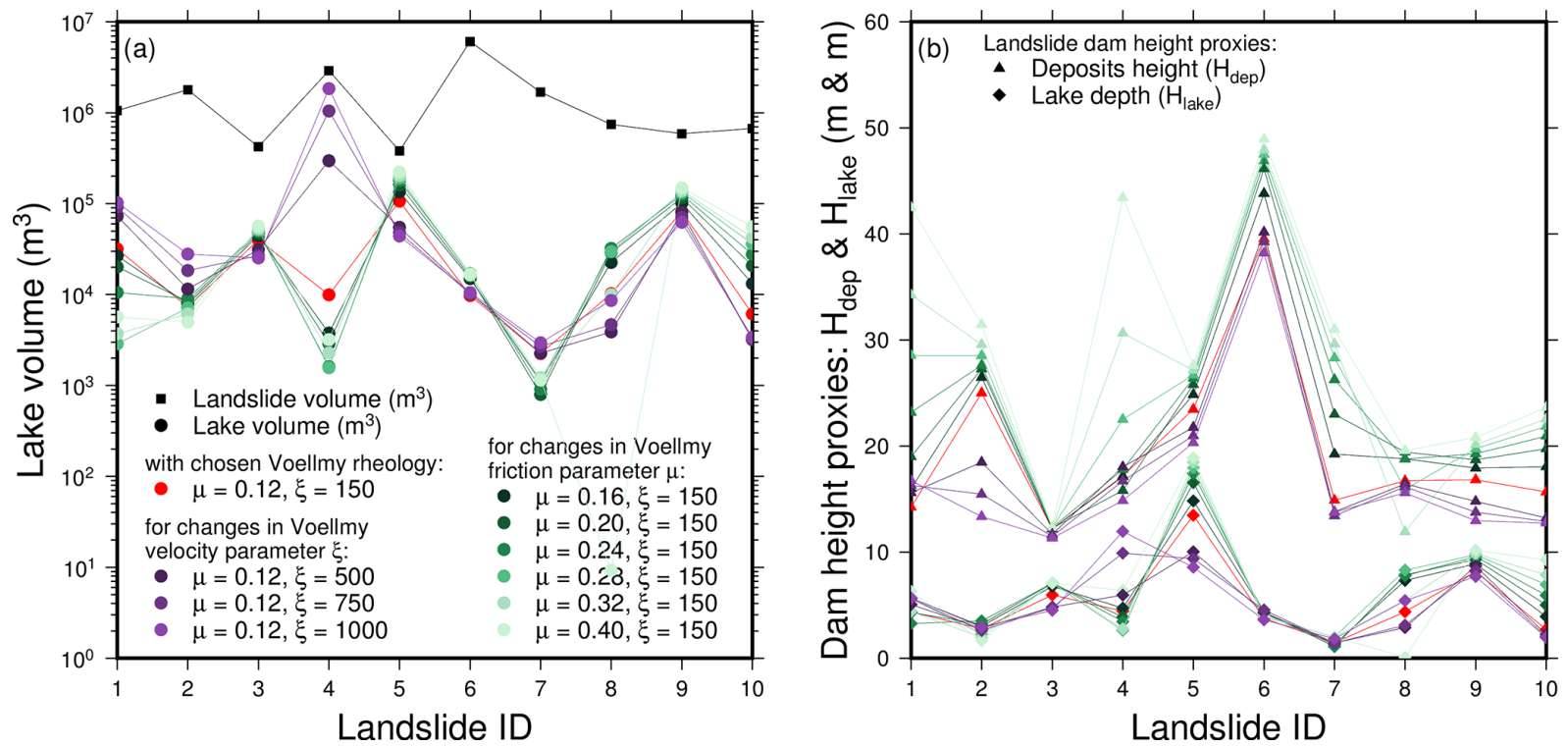

Figure A1. Impact of the Voellmy rheological parameters on lake volumes and landslide damming height proxies for 10 simulated landslides. The indices chosen in the simulation $(\mu=0.12$ and $\xi=150)$ are plotted in red.

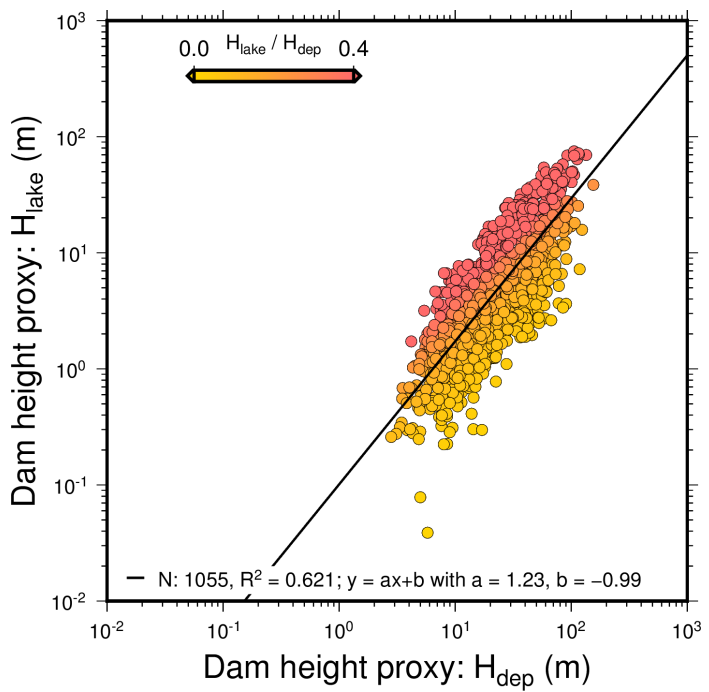

Figure A2. Bi-logarithmic diagram of the landslide dam height proxies: maximum lake depth $H_{\text {lake }}$ in relation to maximum landslide deposit height $H_{\text {dep }}$. We used a color gradient to highlight the change in $\frac{H_{\text {lake }}}{H_{\text {dep }}}$ ratio. We fitted power laws using least squares with vertical misfit and indicated their sample number $N$, coefficient of determination $\left(R^{2}\right)$ and characteristics (slope $a$ and intercept $b$ ). 

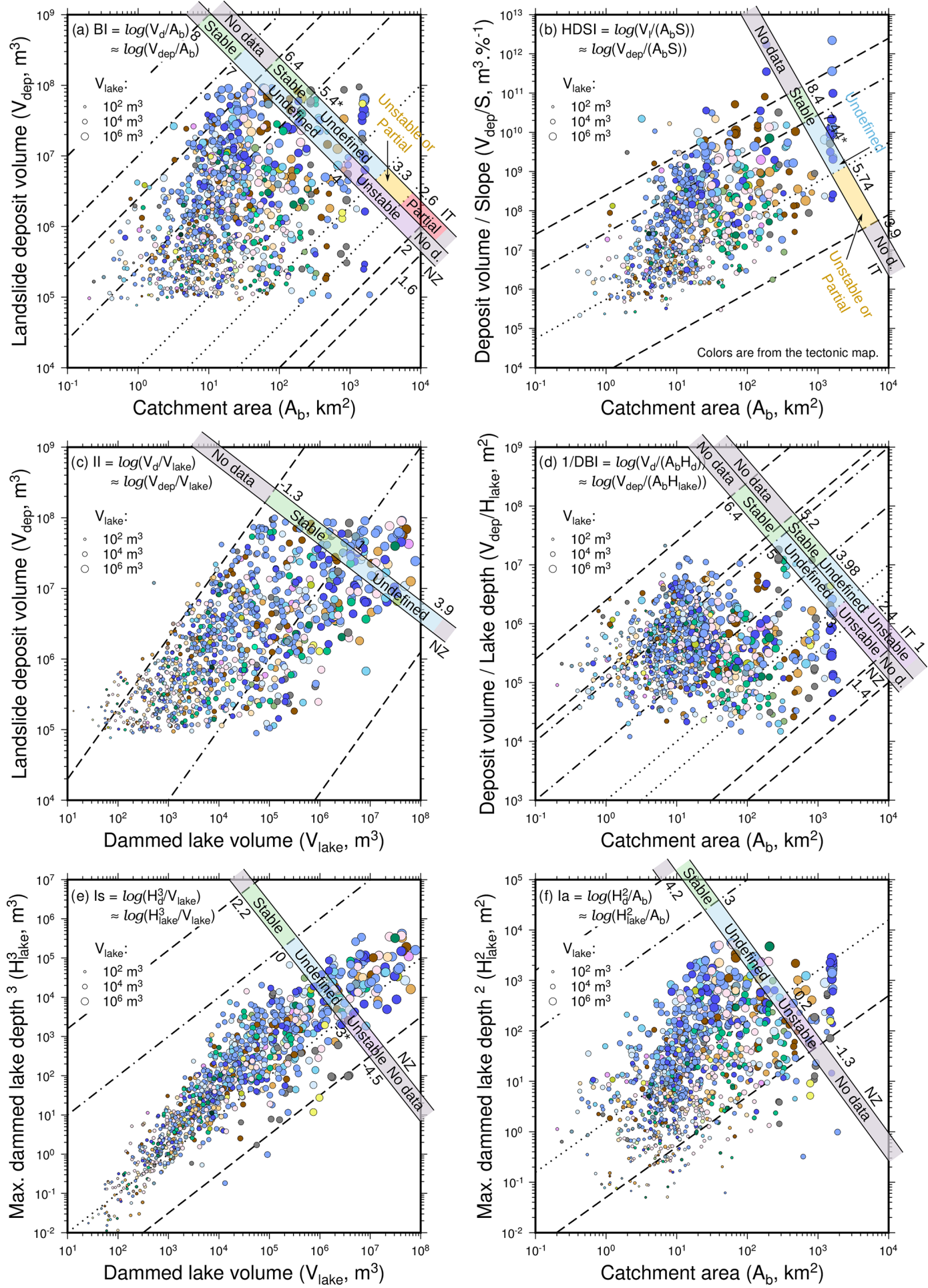

Figure A3. Bi-logarithmic diagrams of landslide dam classification according to two obstruction and stability indices: (a) the blockage index (BI) and (b) the hydromorphological dam stability index (HDSI). Also according to four stability indices: (c) the impoundment index (II), (d) the dimensionless blockage index (DBI), (e) the backstow index (Is) and (f) the basin index (Ia). The circle color represents the tectonic unit and the circle size the logarithm of dammed lake volume. The obstruction and stability ranges from literature are indicated by scales, with the threshold values annotated on the side. Threshold lines are dashed for "No Data", dot-dashed for "Stable" and dotted for "Unstable". We abbreviate NZ for New Zealand (Korup, 2004) and IT for Apennines, Italy (Tacconi Stefanelli et al., 2016). The threshold values with ${ }^{*}$ present a few outliers. The cluster of values with a catchment area of $10^{3} \mathrm{~km}^{2}$ is located in the same area in the Gesäuse mountain range, in the Enns catchment. 

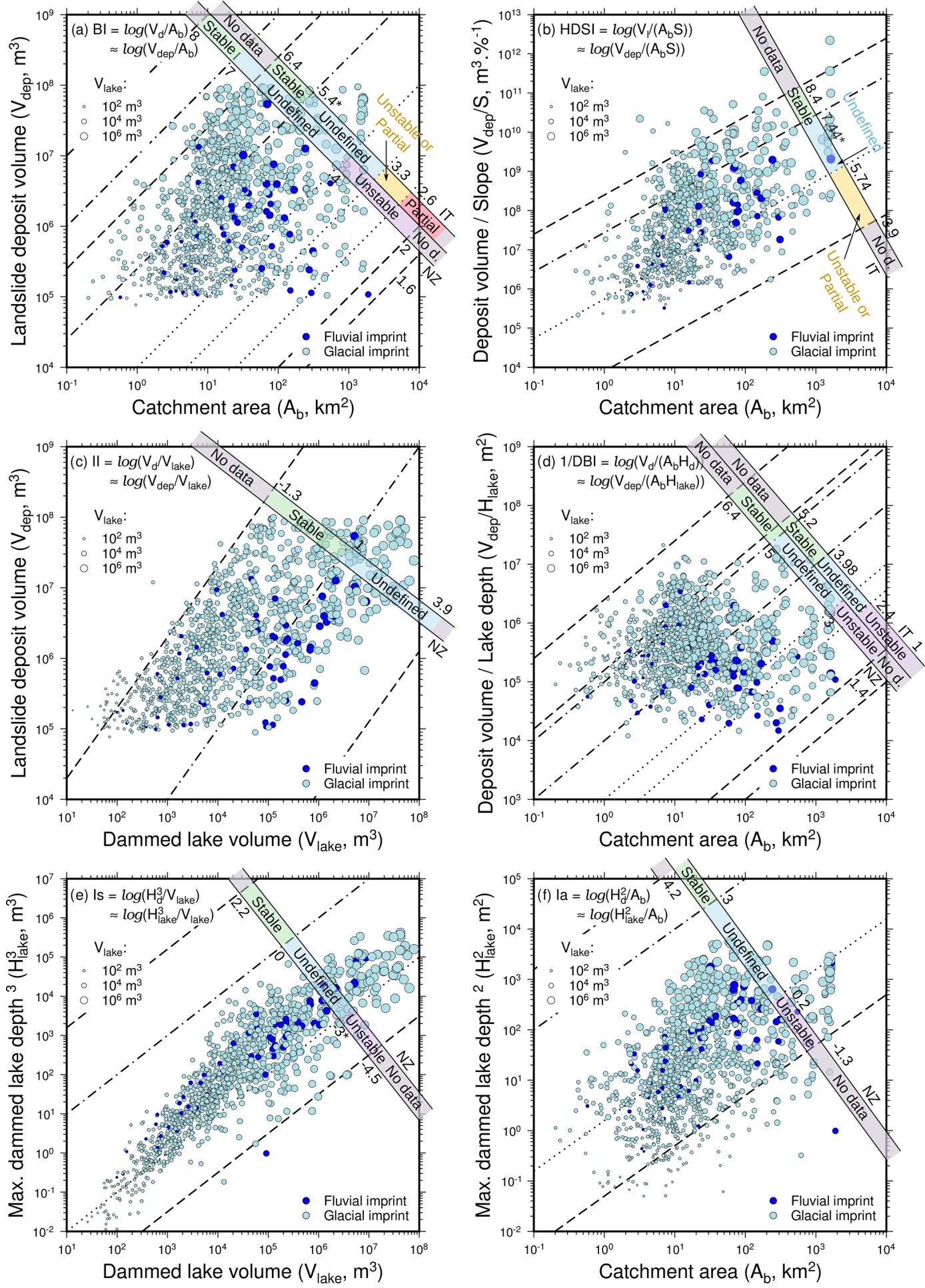

Figure A4. Bi-logarithmic diagrams of landslide dam classification according to two obstruction and stability indices: (a) the blockage index (BI) and (b) the hydromorphological dam stability index (HDSI). Also according to four stability indices: (c) the impoundment index (II), (d) the dimensionless blockage index (DBI), (e) the backstow index (Is) and (f) the basin index (Ia). The circle color represents the glacial imprint and the circle size the logarithm of dammed lake volume. The obstruction and stability ranges from literature are indicated by scales, with the threshold values annotated on the side. Threshold lines are dashed for "No Data", dot-dashed for "Stable" and dotted for "Unstable". We abbreviate NZ for New Zealand (Korup, 2004) and IT for Apennines, Italy (Tacconi Stefanelli et al., 2016). The threshold values with * present a few outliers. The cluster of values with a catchment area of $10^{3} \mathrm{~km}^{2}$ is located in the same area in the Gesäuse mountain range, in the Enns catchment. 


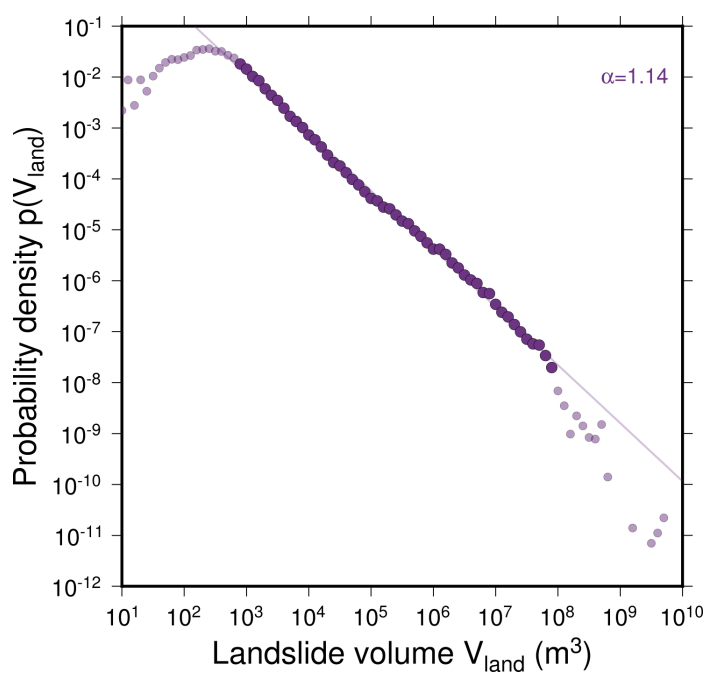

Figure A5. Size distribution of the landslide release volumes. 
Code and data availability. The code is available online and has been encapsulated in a Docker container for easy setup: https://doi.org/10.5281/zenodo.4171597.

Author contributions. GP and DH acquired funding for the project; JR, ALA and GP conceptualized the research question; ALA and JR developed the methodology; ALA, JR and GP validated it; ALA carried out the investigation, formal analysis and visualization; ALA, JR and SH were involved in data curation; ALA, GP and JR wrote the original draft, and ALA, GP, JR, SH, LA, DH and ZD reviewed and edited it; JR and GP supervised the author; GP and $\mathrm{DH}$ were in charge of project administration. All authors have read and agreed to the published version of the manuscript.

Competing interests. The authors declare that they have no conflict of interest.

Acknowledgements. The authors would like to thank Franz Neubauer for the discussions on the geology of the Alps. All maps are created using Generic Mapping Tools (Wessel et al., 2019).

Financial support. This research has been supported by the Austrian Academy of Sciences (ÖAW, Earth System Science research program) through the project RiCoLa (Detection and analysis of landslide-induced river course changes and lake formation). The first author's salary was partly funded by the Marie Andeßner grant (University of Salzburg).

Review statement. This paper was edited by Andreas Günther and reviewed by two anonymous referees.

\section{References}

Aaron, J. and McDougall, S.: Rock avalanche mobility: The role of path material, Eng. Geol., 257, 105126, https://doi.org/10.1016/j.enggeo.2019.05.003, 2019.

Agassiz, L. and Bettannier, J.: Etudes sur les glaciers, Jent et Gassmann, Imprimerie de Ol. Petitpierre, Neuchâtel, 1840.

Anderson, R. S., Molnar, P., and Kessler, M. A.: Features of glacial valley profiles simply explained, J. Geophys. Res.-Earth, 111, F01004, https://doi.org/10.1029/2005JF000344, 2006.

Augustinus, P. C.: Glacial valley cross-profile development: the influence of in situ rock stress and rock mass strength, with examples from the Southern Alps, New Zealand, Geomorphology, 14, 87-97, https://doi.org/10.1016/0169-555X(95)00050-X, 1995.

Bartosch, T., Stüwe, K., and Robl, J.: Topographic evolution of the Eastern Alps: The influence of strike-slip faulting activity, Lithosphere, 9, 384-398, https://doi.org/10.1130/L594.1, 2017.

Baumann, S., Robl, J., Prasicek, G., Salcher, B., and Keil, M.: The effects of lithology and base level on topography in the northern alpine foreland, Geomorphology, 313, 13-26, https://doi.org/10.1016/j.geomorph.2018.04.006, 2018.

Bousquet, R., Schmid, S., Zeilinger, G., Oberhänsli, R., Rosenberg, C., Molli, G., Robert, C., Wiederkehr, M., and Rossi, P.: Tectonic framework of the Alps $\left(1: 1^{\prime} 000^{\prime} 000\right)$, CCGM-CGMW Commission de la Carte Géologique du Monde, 2012.

Brunetti, M. T., Guzzetti, F., and Rossi, M.: Probability distributions of landslide volumes, Nonlin. Processes Geophys., 16, 179-188, https://doi.org/10.5194/npg-16-179-2009, 2009.

Canuti, P., Casagli, N., and Ermini, L.: Inventory of landslide dams in the Northern Apennine as a model for induced flood hazard forecasting, Managing Hydro-Geological Disasters in a Vulnerable Environment, CNR-GNDCI and UNESCO IHP, Perugia, 189-202, 1998.

Casagli, N. and Ermini, L.: Geomorphic analysis of landslide dams in the Northern Apennine, T. Japan. Geomorphol. Union, 20, 219-249, 1999.

Chen, K.-T., Kuo, Y.-S., and Shieh, C.-L.: Rapid Geometry Analysis for Earthquake-induced and Rainfall-induced Landslide Dams in Taiwan, J. Mount. Sci., 11, 360-370, https://doi.org/10.1007/s11629-013-2664-y, 2014.

Christen, M., Kowalski, J., and Bartelt, P.: RAMMS: Numerical simulation of dense snow avalanches in threedimensional terrain, Cold Reg. Sci. Technol., 63, 1-14, https://doi.org/10.1016/j.coldregions.2010.04.005, 2010.

Church, M. and Ryder, J. M.: Paraglacial sedimentation: a consideration of fluvial processes conditioned by glaciation, Geol. Soc. Am. Bull., 83, 3059-3072, 1972.

Costa, J. E.: Floods from dam failures, US Geological Survey, Denver, Colorado, 1-59, https://doi.org/10.3133/ofr85560, 1985.

Costa, J. E. and Schuster, R. L.: Formation and Failure of Natural Dams, Bull. Geol. Soc. Am., 100, 1054-1068, https://doi.org/10.1130/00167606(1988) 100<1054:TFAFON>2.3.CO;2, 1988.

Costa, J. E. and Schuster, R. L.: Documented historical landslide dams from around the world, Open-File Report, United States Geological Survey, 494, available at: http://pubs.er.usgs. gov/publication/ofr91239 (last access: 26 May 2021), 1991.

Crest, Y., Delmas, M., Braucher, R., Gunnell, Y., Calvet, M., and Aster Team: Cirques have growth spurts during deglacial and interglacial periods: Evidence from ${ }^{10} \mathrm{Be}$ and ${ }^{26} \mathrm{Al}$ nuclide inventories in the central and eastern Pyrenees, Geomorphology, 278, 60-77, 2017.

Croissant, T., Steer, P., Lague, D., Davy, P., Jeandet, L., and Hilton, R. G.: Seismic cycles, earthquakes, landslides and sediment fluxes: Linking tectonics to surface processes using a reduced-complexity model, Geomorphology, 339, 87-103, https://doi.org/10.1016/j.geomorph.2019.04.017, 2019.

Cui, P., Yan Zhu, Y., Shun Han, Y., Qing Chen, X., and Qi Zhuang, J.: The 12 May Wenchuan earthquake-induced landslide lakes: Distribution and preliminary risk evaluation, Landslides, 6, 209223, https://doi.org/10.1007/s10346-009-0160-9, 2009.

Davis, W. M.: The sculpture of mountains by glaciers, Scottish Geogr. Mag., 22, 76-89, 1906.

Delaney, K. B. and Evans, S. G.: The 2000 Yigong landslide (Tibetan Plateau), rockslide-dammed lake and outburst flood: Review, remote sensing analysis, and process modelling, Geomorphology, 246, 377-393, https://doi.org/10.1016/j.geomorph.2015.06.020, 2015. 
Dorren, L. K.: A review of rockfall mechanics and modelling approaches, Prog. Phys. Geogr., 27, 69-87, https://doi.org/10.1191/0309133303pp359ra, 2003.

Dufresne, A., Ostermann, M., and Preusser, F.: Riverdamming, late-Quaternary rockslides in the Ötz Valley region (Tyrol, Austria), Geomorphology, 310, 153-167, https://doi.org/10.1016/j.geomorph.2018.03.012, 2018.

Ehlers, J. and Gibbard, P. L.: Quaternary glaciations-extent and chronology: part I: Europe, in: vol. 2, Elsevier, the Netherlands, 2004.

Ermini, L. and Casagli, N.: Criteria for a preliminary assessment of landslide dams evolution, Landslides, in: Proceedings 1st European Conference on Landslides, 24-26 June 2002, Prague, Czech Republic, 24-26, 2002.

Fan, X., van Westen, C. J., Xu, Q., Gorum, T., and Dai, F.: Analysis of landslide dams induced by the 2008 Wenchuan earthquake, J. Asian Earth Sci., 57, 25-37, https://doi.org/10.1016/j.jseaes.2012.06.002, 2012.

Fan, X., Yang, F., Siva Subramanian, S., Xu, Q., Feng, Z., Mavrouli, O., Peng, M., Ouyang, C., Jansen, J. D., and Huang, R.: Prediction of a multi-hazard chain by an integrated numerical simulation approach: the Baige landslide, Jinsha River, China, Landslides, 17, 147-164, https://doi.org/10.1007/s10346-019-013135, 2019.

Fan, X., Dufresne, A., Siva Subramanian, S., Strom, A., Hermanns, R., Tacconi Stefanelli, C., Hewitt, K., Yunus, A. P., Dunning, S., Capra, L., Geertsema, M., Miller, B., Casagli, N., Jansen, J. D., and Xu, Q.: The formation and impact of landslide dams - State of the art, Earth-Sci. Rev., 203, 103116, https://doi.org/10.1016/j.earscirev.2020.103116, 2020.

Fernández, T., Irigaray, C., El Hamdouni, R., and Chacón, J.: Correlation between natural slope angle and rock mass strength rating in the Betic Cordillera, Granada, Spain, Bull. Eng. Geol. Environ., 67, 153-164, https://doi.org/10.1007/s10064-007-0118-x, 2008.

Finnegan, N. J., Roe, G., Montgomery, D. R., and Hallet, B.: Controls on the channel width of rivers: Implications for modeling fluvial incision of bedrock, Geology, 33, 229-232, https://doi.org/10.1130/G21171.1, 2005.

Flint, J.-J.: Stream gradient as a function of order, magnitude, and discharge, Water Resour. Res., 10, 969-973, 1974.

Goudie, A. S.: Quantification of rock control in geomorphology, Earth-Sci. Rev., 159, 374-387, https://doi.org/10.1016/j.earscirev.2016.06.012, 2016.

Hack, J. T.: Studies of longitudinal stream profiles in Virginia and Maryland, in: vol. 294, US Government Printing Office, Washington, DC, 1957.

Hancox, G. T., Perrin, N. D., and Dellow, G. D.: Earthquakeinduced landsliding in New Zealand and implications for MM intensity and seismimc hazard assessment, GNS Science Consultancy Report 43601B, Institute of Geological \& Nuclear Sciences, New Zealand, 1997.

Handy, M. R., Ustaszewski, K., and Kissling, E.: Reconstructing the Alps-Carpathians-Dinarides as a key to understanding switches in subduction polarity, slab gaps and surface motion, Int. J. Earth Sci., 104, 1-26, 2015.

Harbor, J. M. and Wheeler, D. A.: On the mathematical description of glaciated valley cross sections, Earth Surf. Proc. Land., 17, 477-485, 1992.
Hergarten, S.: Topography-based modeling of large rockfalls and application to hazard assessment, Geophys. Res. Lett., 39, L13402, https://doi.org/10.1029/2012GL052090, 2012.

Hergarten, S. and Robl, J.: Modelling rapid mass movements using the shallow water equations in Cartesian coordinates, Nat. Hazards Earth Syst. Sci., 15, 671-685, https://doi.org/10.5194/nhess15-671-2015, 2015.

Hermanns, R.: Landslide Dam, in: Encyclopedia of Natural Hazards, Springer Netherlands, Dordrecht, 602-606, https://doi.org/10.1007/978-1-4020-4399-4_213, 2013.

Hermanns, R. L. and Strecker, M. R.: Structural and lithological controls on large quaternary rock avalanches (sturzstroms) in arid northwestern Argentina, Bull. Geol. Soc. Am., 111, 934-948, https://doi.org/10.1130/00167606(1999)111<0934:SALCOL>2.3.CO;2, 1999.

Hölbling, D., Füreder, P., Antolini, F., Cigna, F., Casagli, N., and Lang, S.: A semi-automated object-based approach for landslide detection validated by persistent scatterer interferometry measures and landslide inventories, Remote Sens., 4, 1310-1336, 2012.

Hungr, O.: Prospects for prediction of landslide dam geometry using empirical and dynamic models, in: Natural and Artificial Rockslide Dams, Springer, Berlin, Heidelberg, 463-477, 2011.

Hungr, O. and Evans, S. G.: Rock avalanche runout prediction using a dynamic model, in: Vol. 1, Proceedings, 7th International Symposium on Landslides, Trondheim, Norway, 233-238, 1996.

Hungr, O. and Evans, S. G.: Entrainment of debris in rock avalanches: An analysis of a long run-out mechanism, Bull. Geol. Soc. Am., 116, 1240-1252, https://doi.org/10.1130/B25362.1, 2004.

Hungr, O., Evans, S. G., Bovis, M. J., and Hutchinson, J. N.: A review of the classification of landslides of the flow type, Environ. Eng. Geosci., 7, 221-238, https://doi.org/10.2113/gseegeosci.7.3.221, 2001.

Hussin, H. Y., Quan Luna, B., Van Westen, C. J., Christen, M., Malet, J. P., and Van Asch, T. W.: Parameterization of a numerical 2-D debris flow model with entrainment: A case study of the Faucon catchment, Southern French Alps, Nat. Hazards Earth Syst. Sci., 12, 3075-3090, https://doi.org/10.5194/nhess12-3075-2012, 2012.

Jiao, R., Herman, F., Beyssac, O., Adatte, T., Cox, S. C., Nelson, F. E., and Neil, H. L.: Erosion of the Southern Alps of New Zealand during the last deglaciation, Geology, 46, 975-978, 2018.

Körner, H.: Reichweite und Geschwindigkeit von Bergstürzen und Fließschneelawinen, Rock Mech,, 8, 225-256, 1976.

Korup, O.: Geomorphometric characteristics of New Zealand landslide dams, Eng. Geol., 73, 13-35, https://doi.org/10.1016/j.enggeo.2003.11.003, 2004.

Korup, O.: Geomorphic hazard assessment of landslide dams in South Westland, New Zealand: Fundamental problems and approaches, Geomorphology, 66, 167-188, https://doi.org/10.1016/j.geomorph.2004.09.013, 2005.

Korup, O.: Rock type leaves topographic signature in landslidedominated mountain ranges, Geophys. Res. Lett., 35, L11402, https://doi.org/10.1029/2008GL034157, 2008.

Kuhn, C.: Austrian Rockslides, available at: http://geol-info.at/ index.htm, last access: 27 July 2020. 
Larsen, I. J., Montgomery, D. R., and Korup, O.: Landslide erosion controlled by hillslope material, Nat. Geosci., 3, 247-251, https://doi.org/10.1038/ngeo776, 2010.

Lin, C. H. and Lin, M. L.: Evolution of the large landslide induced by Typhoon Morakot: A case study in the Butangbunasi River, southern Taiwan using the discrete element method, Eng. Geol., 197, 172-187, https://doi.org/10.1016/j.enggeo.2015.08.022, 2015.

Lucas, A., Mangeney, A., and Ampuero, J. P.: Frictional velocityweakening in landslides on Earth and on other planetary bodies, Nat. Commun., 5, 3417, https://doi.org/10.1038/ncomms4417, 2014.

May, C., Roering, J., Eaton, L. S., and Burnett, K. M.: Controls on valley width in mountainous landscapes: The role of landsliding and implications for salmonid habitat, Geology, 41, 503-506, https://doi.org/10.1130/G33979.1, 2013.

Mergili, M., Mergili, M., Jaboyedoff, M., Pullarello, J., and Pudasaini, S. P.: Back calculation of the 2017 Piz Cengalo-Bondo landslide cascade with ravaflow: What we can do and what we can learn, Nat. Hazards Earth Syst. Sci., 20, 505-520, https://doi.org/10.5194/nhess-20-505-2020, 2020.

Montgomery, D. R.: Slope distributions, threshold hillslopes, and steady-state topography, Am. J. Sci., 301, 432-454, https://doi.org/10.2475/ajs.301.4-5.432, 2001.

Montgomery, D. R. and Korup, O.: Preservation of inner gorges through repeated Alpine glaciations, Nat. Geosci., 4, 62-67, 2011.

NASA/METI/AIST/Japan Spacesystems and US/Japan ASTER Science Team: ASTER Global Digital Elevation Model V003 [Data set], NASA EOSDIS Land Processes DAAC, https://doi.org/10.5067/ASTER/ASTGTM.003, 2019.

Nichol, J. and Wong, M.: Satellite remote sensing for detailed landslide inventories using change detection and image fusion, Int. J. Remote Sens., 26, 1913-1926, 2005.

Open Data Österreich: Digitales Geländemodell aus Airborne Laserscan Daten, Höhenangaben des Geländes im Raster von $10 \mathrm{~m} \times 10 \mathrm{~m}$, Daten im Format GeoTIFF (EPSG: 31287), Datenverantwortliche Stelle: Geoland.at, available at: https://www.data.gv.at/katalog/dataset/ b5de6975-417b-4320-afdb-eb2a9e2a1dbf (last access: 24 May 2021), 2015.

Penck, A.: Glacial features in the surface of the Alps, J. Geol., 13, 1-19, 1905.

Perrin, N. and Hancox, G.: Landslide-dammed lakes in New Zealand - Preliminary studies on their distribution, causes and effects, in: Landslides, edited by: Bell, D. H., A. A. Balkema, Rotterdam, 1992.

Peruccacci, S., Brunetti, M. T., Luciani, S., Vennari, C., and Guzzetti, F.: Lithological and seasonal control on rainfall thresholds for the possible initiation of landslides in central Italy, Geomorphology, 139-140, 79-90, https://doi.org/10.1016/j.geomorph.2011.10.005, 2012.

Popinet, S.: Gerris: A tree-based adaptive solver for the incompressible Euler equations in complex geometries, J. Compu. Phys., 190, 572-600, https://doi.org/10.1016/S0021-9991(03)00298-5, 2003.

Prasicek, G., Larsen, I. J., and Montgomery, D. R.: Tectonic control on the persistence of glacially sculpted topography, Nat. Commun., 6, 1-6, 2015.
Reichenbach, P., Rossi, M., Malamud, B. D., Mihir, M., and Guzzetti, F.: A review of statistically-based landslide susceptibility models, Earth-Sci. Rev., 180, 60-91, https://doi.org/10.1016/j.earscirev.2018.03.001, 2018.

Robl, J., Hergarten, S., and Stüwe, K.: Morphological analysis of the drainage system in the Eastern Alps, Tectonophysics, 460, 263-277, https://doi.org/10.1016/j.tecto.2008.08.024, 2008.

Robl, J., Prasicek, G., Hergarten, S., and Stüwe, K.: Alpine topography in the light of tectonic uplift and glaciation, Global Planet. Change, 127, 34-49, https://doi.org/10.1016/j.gloplacha.2015.01.008, 2015.

Sanne, M. J.: Modelling the 1987 Val Pola rock avalanche using the shallow water equations, Tech. rep., Faculty of Environment and Natural Resources Albert Ludwigs University of Freiburg, Freiburg, 2015.

Savage, S. B. and Hutter, K.: The motion of a finite mass of granular material down a rough incline, J. Fluid Mech., 199, 177-215, https://doi.org/10.1017/S0022112089000340, 1989.

Schmid, S. M., Fügenschuh, B., Kissling, E., and Schuster, R.: Tectonic map and overall architecture of the Alpine orogen, Eclogae Geologicae Helvetiae, 97, 93-117, https://doi.org/10.1007/s00015-004-1113-x, 2004.

Schraml, K., Thomschitz, B., Mcardell, B. W., Graf, C., and Kaitna, R.: Modeling debris-flow runout patterns on two alpine fans with different dynamic simulation models, Nat. Hazards Earth Syst. Sci., 15, 1483-1492, https://doi.org/10.5194/nhess15-1483-2015, 2015.

Schrott, L., Hufschmidt, G., Hankammer, M., Hoffmann, T., and Dikau, R.: Spatial distribution of sediment storage types and quantification of valley fill deposits in an alpine basin, Reintal, Bavarian Alps, Germany, Geomorphology, 55, 45-63, 2003.

Schwanghart, W. and Kuhn, N. J.: TopoToolbox: A set of Matlab functions for topographic analysis, Environ. Model. Softw., 25, 770-781, https://doi.org/10.1016/j.envsoft.2009.12.002, 2010.

Schwanghart, W. and Scherler, D.: Short Communication: TopoToolbox 2 - MATLAB-based software for topographic analysis and modeling in Earth surface sciences, Earth Surf. Dynam., 2, 1-7, https://doi.org/10.5194/esurf-2-1-2014, 2014.

Selby, M. J.: Controls on the stability and inclinations of hillslopes formed on hard rock, Earth Surf. Proc. Land., 7, 449-467, https://doi.org/10.1002/esp.3290070506, 1982.

Shuster, D. L., Ehlers, T. A., Rusmoren, M. E., and Farley, K. A.: Rapid glacial erosion at $1.8 \mathrm{Ma}$ revealed by ${ }^{4} \mathrm{He} /{ }^{3} \mathrm{He}$ thermochronometry, Science, 310, 1668-1670, 2005.

Snyder, D. T. and Brownell, D. L.: Hydrogeologic setting and preliminary estimates of hydrologic components for Bull Run Lake and the Bull Run Lake drainage basin, Multnomah and Clackamas counties, Oregon, 96-4064, US Department of the Interior, US Geological Survey, Portland, Oregon, https://doi.org/10.3133/wri964064, 1996.

Stähli, M., Sättele, M., Huggel, C., McArdell, B. W., Lehmann, P., Van Herwijnen, A., Berne, A., Schleiss, M., Ferrari, A., Kos, A., Or, D., and Springman, S. M.: Monitoring and prediction in early warning systems for rapid mass movements, Nat. Hazards Earth Syst. Sci., 15, 905-917, https://doi.org/10.5194/nhess-15905-2015, 2015.

Swanson, F. J., Oyagi, N., and Tominaga, M.: Landslide Dams in Japan, Geotech. Spec. Publ., 3, 131-145, 1986. 
Tacconi Stefanelli, C., Catani, F., and Casagli, N.: Geomorphological investigations on landslide dams, Geoenviron. Disast., 2, 21, https://doi.org/10.1186/s40677-015-0030-9, 2015.

Tacconi Stefanelli, C., Segoni, S., Casagli, N., and Catani, F.: Geomorphic indexing of landslide dams evolution, Eng. Geol., 208, 1-10, https://doi.org/10.1016/j.enggeo.2016.04.024, 2016.

Tebbens, S. F.: Landslide Scaling: A Review, Earth Space Sci., 7, e2019EA000662, https://doi.org/10.1029/2019EA000662, 2020.

Valla, P. G., Shuster, D. L., and Van Der Beek, P. A.: Significant increase in relief of the European Alps during mid-Pleistocene glaciations, Nat. Geosci., 4, 688-692, 2011.
Voellmy, A.: Über die Zerstörungskraft von Lawinen, Schweizerische Bauzeitung, 73, 159-165, https://doi.org/10.5169/seals61891, 1955

Wessel, P., Luis, J. F., Uieda, L., Scharroo, R., Wobbe, F., Smith, W. H., and Tian, D.: The Generic Mapping Tools Version 6, Geochem. Geophy. Geosy., 20, 5556-5564, https://doi.org/10.1029/2019GC008515, 2019.

Whitbread, K., Jansen, J., Bishop, P., and Attal, M.: Substrate, sediment, and slope controls on bedrock channel geometry in postglacial streams, J. Geophys. Res.-Earth, 120, 779-798, https://doi.org/10.1002/2014JF003295, 2015. 